\title{
The Role of Adenosine Tone and Adenosine Receptors in Huntington's Disease
}

\author{
David Blum, ${ }^{1}$ Yijuang Chern, ${ }^{2}$ Maria Rosaria Domenici, ${ }^{3}$ Luc Buée, ${ }^{1}$ \\ Chien-Yu Lin, ${ }^{2}$ William Rea, ${ }^{4}$ Sergi Ferré, ${ }^{4}$ and Patrizia Popoli ${ }^{3}$
}

Huntington's disease (HD) is a hereditary neurodegenerative disorder caused by a mutation in the IT15 gene that encodes for the huntingtin protein. Mutated hungtingtin, although widely expressed in the brain, predominantly affects striato-pallidal neurons, particularly enriched with adenosine $\mathrm{A}_{2 \mathrm{~A}}$ receptors $\left(\mathrm{A}_{2 \mathrm{~A}} \mathrm{R}\right)$, suggesting a possible involvement of adenosine and $\mathrm{A}_{2 \mathrm{~A}} \mathrm{R}$ is the pathogenesis of HD. In fact, polymorphic variation in the ADORA2A gene influences the age at onset in $\mathrm{HD}$, and $\mathrm{A}_{2 \mathrm{~A}} \mathrm{R}$ dynamics is altered by mutated huntingtin. Basal levels of adenosine and adenosine receptors are involved in many processes critical for neuronal function and homeostasis, including modulation of synaptic activity and excitotoxicity, the control of neurotrophin levels and functions, and the regulation of protein degradation mechanisms. In the present review, we critically analyze the current literature involving the effect of altered adenosine tone and adenosine receptors in HD and discuss why therapeutics that modulate the adenosine system may represent a novel approach for the treatment of HD.

Keywords: Huntington's disease, adenosine, adenosine receptors, equilibrative nucleoside transporter, animal models

\section{Pathogenic Mechanisms of Huntington's Disease Overview}

$\mathbf{H}$ UNTINGTON'S DISEASE (HD) is an inherited neurodegenerative disorder that is caused by a single, autosomal dominant gene mutation. HD generally affects young adults and is characterized by involuntary, abnormal movements and postures (chorea, dyskinesia, dystonia), psychiatric disturbances, and cognitive alterations. ${ }^{1,2}$ It is estimated that 1 in 10,000 people have HD and this disorder is fatal within 15-20 years after the onset of symptoms. Multiple brain regions, including several cortical and subcortical regions (cerebral cortex, layers III, V, and VI; pallidum, sub-thalamic nucleus, cerebellum), show signs of neurodegeneration, but the most pronounced neuronal loss is present in the caudate nucleus and the putamen of the striatum. ${ }^{3}$ Within the striatum, the striato-pallidal, medium spiny neurons (MSN) that express enkephalin, dopamine $D_{2}$ receptors $\left(D_{2} R\right)$ and adenosine $A_{2 A}$ receptors $\left(A_{2 A} R\right),{ }^{4,5}$ appear to be the most vulnerable. ${ }^{6,7}$
HD is caused by a mutation in the IT15 gene that encodes for the protein huntingtin $(\mathrm{Htt}){ }^{8}$ This mutation consists of a CAG trinucleotide repeat that is translated into an abnormal polyglutamine (polyQ) tract in the $\mathrm{N}$-terminal region of the protein. The disease is present in all cases where the CAG repeat length is greater than 40, and longer CAG repeats are associated with an earlier onset of disease symptoms. ${ }^{9}$ Although onset of the disease is primarily correlated to the number of $\mathrm{CAG}$ repetitions, this only accounts for about $60 \%$ of the variation in the age at onset (AAO). ${ }^{9}$ This supports the idea that other genetic and environmental factors may be influential components that can modify the expression of the disease and potentially be used as therapeutic targets.

$\mathrm{Htt}$ is a large protein of about $350 \mathrm{kD}$ that is expressed in various tissues in the body and is involved in many important cellular functions. ${ }^{1,10-13} \mathrm{Htt}$ is widely distributed in the central nervous system, particularly in cortical pyramidal neurons, striatal interneurons, Purkinje cells, ${ }^{14,15}$ and glial cells. ${ }^{16}$ To date, the exact cellular

\footnotetext{
${ }^{1}$ University of Lille, Inserm, CHU Lille, UMR-S 1172 - JPArc, LabEx DISTALZ, Lille, France.

${ }^{2}$ Institute of Biomedical Sciences, Academia Sinica, Taipei, Taiwan.

${ }^{3}$ National Center for Drug Research and Evaluation, Istituto Superiore di Sanità, Rome, Italy.

${ }^{4}$ Integrative Neurobiology Section, National Institute on Drug Abuse, National Institutes of Health, Baltimore, Maryland.
} 
function of $\mathrm{Htt}$ is still not completely understood. ${ }^{1,17} \mathrm{Htt}$ is involved in many physiological functions including early embryonic development, ${ }^{18}$ fate of cortical progenitors, ${ }^{19,20}$ axonal transport ${ }^{21,22}$ and brain-derived neurotrophic factor (BDNF) expression/transport. ${ }^{23}$ When the $\mathrm{Htt}$ protein becomes mutated $(\mathrm{mHtt})$, not only is normal Htt function impaired, but several mechanisms important for neuronal activity and survival become impaired, leading to a gain of function that can be toxic to the cells. ${ }^{13}$

It is not clear whether HD is a prion-like disorder comparable to Alzheimer's or Parkinson's diseases, but experimental evidence suggests that $\mathrm{mHtt}$ triggers mis-conformation of wild-type (WT) Htt and neuropathological observations in patients who received intracerebral allografts support the transfer of HD pathology from cell to cell. ${ }^{24}$ This supports the idea that transcellular propagation of protein aggregation could underlie the pathological progression in HD. ${ }^{24}$ In the next sections, we will discuss excitotoxicity, BDNF function, and glial cells: specifically, how mHtt impairs these pathways, and how these systems are likely to be modulated by adenosine receptors.

\section{Excitotoxicity and mitochondrial dysfunctions}

Excitotoxicity is the pathological process where nerve cells are damaged or killed due to excessive stimulation of receptors by neurotransmitters such as glutamate. There is evidence indicating that dysfunctions of the glutamatergic system in the striatum account for the toxic effect of mHtt in HD, although it is unclear whether this is mainly due to a presynaptic mechanism, with the over-release of glutamate by cortical afferents. ${ }^{25}$ Neuronal impairments that lead to excitotoxicity include poor reuptake of glutamate by glial cells, the hypersensitivity of N-methyl-D-aspartate (NMDA) receptors, and the dysregulation of mitochondrial function. ${ }^{26-28} \mathrm{mHtt}$ has been shown to impair the expression of astrocytic glutamate transporters, thus leading to an increase in glutamate in the synaptic clef. ${ }^{16,29-31}$

Several studies have shown that there is abnormal NMDA receptor arrangement and activity in HD. In striatal MSN, mHtt increases the activity of the NR2B subunit of the NMDA receptor, reducing its ability to interact with the docking protein PSD95. ${ }^{32-34}$ Also, R6/2 transgenic HD mice show an enhanced response to NMDA, ${ }^{35}$ and a reduced NR2A/NR2B ratio, a measurement of excitotoxic cell death vulnerability. ${ }^{36,37}$ These abnormal interactions lead to increased NMDA firing, altered NMDA receptor trafficking, ${ }^{28}$ and neuronal vulnerability to NMDA. ${ }^{34,38}$ These data suggest that the increased expression of extrasynaptic, NR2B-contaning NMDA receptors may contribute to NMDA's deleterious effects on the neuron. ${ }^{39}$

In $\mathrm{HD}$, the increase in NMDA response is likely affected by environmental modulation of the NMDA re- ceptor other than glutamate. Quinolinic acid (QA), is a downstream product of the kynurenin pathway that degrades tryptophan and acts as an NMDA agonist. QA stimulates glutamate release from cortico-striatal endings, ${ }^{40,41}$ and is able to produce lesions that mimic those seen in HD patients. $^{42}$ In the striatum, endogenous increases in QA have been demonstrated in the early stage of HD in both humans and animal models. ${ }^{4,44}$

Mitochondrial dysregulation may lead to excitotoxicity. Several imaging studies have revealed an early metabolic dysfunction in the striatum of HD patients, ${ }^{26,45,46}$ and the severity of these metabolic alterations correlate with the size of the CAG expansion. ${ }^{47}$ Several postmortem studies point to reduced activity of complex II-III, including succinate dehydrogenase in the caudate nucleus of HD patients. ${ }^{48-50}$ This loss of complex II activity in the striatum is due to the reduced expression of complex II subunits, ${ }^{51}$ and the presence of dopamine increases the vulnerability of these striatal neurons to $\mathrm{mHtt}$ toxicity. ${ }^{52}$ Complex II inhibition shows a specific degeneration profile in animals treated with the irreversible complex II inhibitor 3-nitropropionic acid (3-NP), ${ }^{26}$ suggesting that complex II inhibition may play a significant role in the striatal degeneration that is seen in HD.

Several other works have reported mitochondrial alterations resulting from $\mathrm{mHtt}$. $\mathrm{mHtt}$ found localized in the neuronal mitochondrial membrane ${ }^{53}$ has been shown to impair mitochondrial biogenesis, fission, ${ }^{54,55}$ axonal transport, ${ }^{56}$ membrane potential, ${ }^{53}$ ATP production, ${ }^{57,58}$ and calcium handling. ${ }^{53,59}$ Interestingly, a dysregulation of mitophagy in the mitochondria is also present in HD, and the prevention of mitochondrial fission and cristae remodeling has been shown to delay HD progression. ${ }^{60}$

Since mitochondrial defects represent one condition that can contribute to neuronal excitotoxicity in $\mathrm{HD},{ }^{27,26}$ the rescue of impaired mitochondria ${ }^{61}$ and correcting poor energy homeostasis might represent a valuable therapeutic approach to HD. ${ }^{60,62,63}$

\section{Brain-derived neurotrophic factor}

BDNF is a neurotropic growth hormone, present in the mammalian brain, involved in a variety of brain processes including synaptic activity. It is also vital for neuronal development, differentiation, and plasticity. ${ }^{64} \mathrm{BDNF}$ is secreted and transported through neurons in the cerebral cortex and is released at nerve endings in the striatum. ${ }^{65}$

In HD, mHtt alters BDNF transcription, ${ }^{66}$ trafficking and axonal transport, ${ }^{22}$ and it downregulates a set of genes, including the one coding BDNF, resulting in a negative effect on the silencing activity of the RE1/NRSE protein seen in WT Htt. ${ }^{67} \mathrm{mHtt}$ also alters the axonal transport of BDNF vesicles, ${ }^{68}$ and post-Golgi trafficking. ${ }^{69}$ More recently, it has been shown that abnormal interactions between pro-BDNF and Htt-associated protein 1 can lead to the alterations in BDNF transport that is seen in HD. ${ }^{70}$ 
BDNF impairment is critically involved in the early vulnerability of striato-pallidal neurons in HD, and increasing BDNF, by gene overexpression, pharmacological or environmental modulation, has been shown to be beneficial in several experimental models of HD. ${ }^{71-77}$

\section{Two major protein degradation systems:} Proteasome and autophagy

In $\mathrm{HD}$, the expansion of polyglutamine (polyQ) in the $\mathrm{N}$-terminal region of $\mathrm{Htt}$ causes protein misfolding and aggregation. ${ }^{78-80}$ The ubiquitin-proteasome system (UPS) degrades damaged or misfolded proteins by E3 ligase targeted polyubiquitination, ${ }^{81,82}$ and global changes in the ubiquitin system, an indicator of the UPS function, has been found in both HD patients and in animal models of HD. ${ }^{83-85} \mathrm{mHtt}$ causes the suppression of UPS function in the cells and brains of HD patients and in animal models, ${ }^{86-88}$ while the enhancement of UPS activity enables soluble $\mathrm{mHtt}$ to degrade and improves proteasome function and motor coordination in HD. ${ }^{63,89-94}$

Macroautophagy, or autophagy, degrades aggregated proteins in the body by delivering them to the lysosome, and is essential for cellular function. ${ }^{95} \mathrm{Htt}$ has been found to function as an important regulator and substrate for selective autophagy. ${ }^{96,97}$ In HD, it has been shown that autophagic vacuoles are unable to recognize cytosolic cargo, and this causes slower turnover and accumulation of $\mathrm{mHtt} .{ }^{98,99}$ Research supports the hypothesis that the clearance of $\mathrm{mHtt}$ is important for the treatment of HD, and that the upregulation of the autophagic process can produce beneficial effects. ${ }^{91,100-103}$

\section{Non-neuronal (glial) and peripheral cells}

Even though neuronal cells are preferentially damaged in $\mathrm{HD}, \mathrm{mHtt}$ is also expressed in glial cells. ${ }^{16,104-106}$ The presence of $\mathrm{mHtt}$ in astrocytes and other glial cells is associated with age-dependent neurological symptoms, contributes to neuronal excitotoxicity, and can lead to HD pathogenesis..$^{16,30,107-111}$ Specifically, mHtt impairs glycolysis, ${ }^{112}$ increases glutamate synthesis, ${ }^{113}$ causes a reduction in GABA release, ${ }^{114}$ reduces the production and release of trophic factors, ${ }^{107,115}$ decreases the expression of potassium channel that leads to neuronal excitotoxicity, ${ }^{116}$ and causes a dysfunction in calcium and glutamate signaling. ${ }^{117}$

In HD, the abnormal function of microglia can cause an overactivation of the inflammatory response that is like the response seen in other neurodegenerative diseases. ${ }^{109,110}$ A recent study indicates that $\mathrm{mHtt}$ in glia can create a disease phenotype in normal mice, while normal glia can abolish the disease phenotype in transgenic HD mice. This study strongly suggests a causal role for glia in HD. ${ }^{118}$

$\mathrm{mHtt}$ is also expressed in peripheral cells and can alter their normal physiology. $\mathrm{mHtt}$ expressed in hepatocytes can suppress the activity of the urea cycle, and can cause high blood ammonia. ${ }^{19,120} \mathrm{mHtt}$ expressed in the immune system leads to enhanced immune activation that can be detected in the early disease stages in both humans and mice. Thus, elevated inflammatory cytokines and chemokines levels are present in HD patients, and it has been proposed that high levels of $\mathrm{mHtt}$ in monocytes and $\mathrm{T}$ cells are significantly associated with the disease progression. ${ }^{121}$ These data suggest that the expression level of $\mathrm{mHtt}$ in immune cells of patients might be a useful, noninvasive disease biomarker for identifying HD. ${ }^{122}$

\section{Dysfunction of Striatal Adenosine Receptors in HD}

\section{Striatal adenosine neurotransmission}

Adenosine plays a fundamental role in modulating dopaminergic and glutamatergic neurotransmission in the striatum. ${ }^{123}$ The main neuronal inputs into the striatum are dopaminergic and glutamatergic in nature, and both converge in the dendritic spines of the MSN, the predominant neuronal population in the striatum. ${ }^{124}$ Glutamate terminals make a tight, tripartite synapse with the head of the dendritic spines and with astrocytes, ${ }^{125}$ while dopamine terminals make lose contact with the neck of the dendritic spines, allowing for dopamine to interact with dopamine receptors located around the synapses by volume transmission. ${ }^{123,126}$

"Local module" can be defined as the minimal portion of neurons and glial cells that combine and operate as an independent and functional, integrative unit. ${ }^{123}$ The "striatal spine module" is the local module centered in the dendritic spine of the MSN, and includes the glutamatergic and dopaminergic terminals and astrocytic processes. ${ }^{123}$ Under normal conditions, ATP released by astrocytic vesicles is rapidly converted to adenosine by ectonucleotidases and this occurs within the striatal spine module. ${ }^{127,128}$ The effects of extracellular adenosine are primarily mediated by adenosine $A_{1}$ receptors $\left(A_{1} R\right)$ and $A_{2 A} R$ that are localized in the different locations of the striatal spine module. Both are $G$ proteincoupled receptors (GPCRs), with $\mathrm{A}_{1} \mathrm{R}$ coupling to the inhibitory Gi/o protein and $\mathrm{A}_{2 \mathrm{~A}} \mathrm{R}$ coupling to the excitatory Gs/olf protein. ${ }^{128}$ Both are co-localized in the glutamatergic terminals and astrocytes, where they form $\mathrm{A}_{1} \mathrm{R}-\mathrm{A}_{2 \mathrm{~A}} \mathrm{R}$ heteromers. ${ }^{129}$ These heteromers act as a concentrationdependent switch in the glutamatergic terminals, with activation of $A_{1} R$ inhibiting glutamate release, while activation of $A_{2 A} R$ shuts down $A_{1} R$ signaling and stimulates glutamate release. ${ }^{129}$

Adenosine has higher affinity for $A_{1} R$ than it has for $A_{2 A} R$, and, presynaptically, it only tonically activates $A_{1} R$. Thus, gene-targeted vesicular release of ATP from the astrocytes leads to a loss of $A_{1} R$-mediated tonic inhibition of presynaptic hippocampal glutamatergic transmission. ${ }^{127}$ Presynaptic $\mathrm{A}_{2 \mathrm{~A}} \mathrm{R}$ on the other hand are only activated by phasic increases in adenosine. This normally 
occurs when glutamatergic inputs are activated, leading to a release of ATP by neurons and glial cells that is later converted to adenosine by 5-nucleotidases. ${ }^{128}$ When there is a phasic increase of adenosine, activation of $\mathrm{A}_{2 \mathrm{~A}} \mathrm{R}$ negatively modulates $\mathrm{A}_{1} \mathrm{R}$ signaling in the heteromer resulting in an increase in glutamate release. ${ }^{130-134}$ This same interaction is also seen in cultured cortical astrocytes, where activation of the $\mathrm{A}_{1} \mathrm{R}-\mathrm{A}_{2 \mathrm{~A}} \mathrm{R}$ heteromer has a modulatory effect on GABA uptake. ${ }^{135}$ In dopaminergic terminals, only $A_{1} R$ are expressed, resulting in the tonic inhibition of dopamine release. ${ }^{132}$

Postsynaptically, $\mathrm{A}_{1} \mathrm{R}$ and $\mathrm{A}_{2 \mathrm{~A}} \mathrm{R}$ are highly expressed in the somatodendritic region of striatal MSNs, and particularly, in the dendritic spines. ${ }^{136}$ They are not co-localized but are segregated into two phenotypically distinct neuronal populations that connect the striatum with the output structures of the basal ganglia. ${ }^{124}$ The striato-nigral neurons of the direct motor pathway, connect the striatum to the substantia nigra pars reticulata. These neurons selectively express $A_{1} R$ and $D_{1} R$ (and $D_{3} R$ in the ventral striatum). ${ }^{136-138}$ The striato-pallidal neurons of the indirect motor pathway, connects the striatum with the lateral segment of the globus pallidus and the ventral pallidum, and selectively expresses $\mathrm{A}_{2 \mathrm{~A}} \mathrm{R}$ and $D_{2} R$. ${ }^{4,136} A_{1} R$ and D1R and $A_{2 A} R$ and $D_{2} R$ form specific receptor complexes, the $A_{1} R-D 1 R$ and $A_{2 A} R-D_{2} R$ heteromers. ${ }^{136,139-141}$ These heteromers act as molecular devices by which endogenous adenosine, when binding to the respective adenosine receptor, tonically inhibits the affinity and signaling of its respective dopamine receptor. Postsynaptic $\mathrm{A}_{2 \mathrm{~A}} \mathrm{R}$, differently from presynaptic $\mathrm{A}_{2 \mathrm{~A}} \mathrm{R}$, are therefore tonically activated, which produces significant behavioral and biochemical effects that can be disclosed when $\mathrm{A}_{2 \mathrm{~A}} \mathrm{R}$ is blocked after the administration of an antagonist (see below). ${ }^{142}$

\section{Adenosine receptor single nucleotide polymorphisms and caffeine intake}

In early pathological stages of HD and even in symptomatic patients with a grade of 0 on Vonsattel's neuropathological severity in $H D$ scale, both $D_{2} R$ and $A_{2 A} R$ are significantly and differentially downregulated when compared with $\mathrm{D}_{1} \mathrm{R} .^{6}$ These data suggest a selective functional alteration in this MSN subpopulation, and this is not surprising considering the preferential vulnerability of the striato-pallidal neurons in HD. ${ }^{6,7}$ Using different HD mouse models, downregulation of $\mathrm{A}_{2 \mathrm{~A}} \mathrm{R}$ has also been reported, and several studies imply that the $\mathrm{mHtt}$ in these HD mice causes abnormal $\mathrm{A}_{2 \mathrm{~A}} \mathrm{R}$ signaling and amplification. ${ }^{61}$

In HD, questions remain whether the changes seen in $\mathrm{A}_{2 \mathrm{~A}} \mathrm{R}$ expression and function are markers of selective degeneration of indirect MSNs, or if they are involved in the pathological process. Genetic studies suggest that changes in $\mathrm{A}_{2 \mathrm{~A}} \mathrm{R}$ are involved in the pathogenesis of the disease. Three single nucleotide polymorphisms in the ADORA2A gene that have nearly complete linkage disequilibrium and can potentially modify $\mathrm{A}_{2 \mathrm{~A}} \mathrm{R}$ transcription are $r s 5751876$ (C>T substitution in exon 5), rs35320474 ( $\mathrm{T}$ deletion in the $3^{\prime}$ untranslated region that includes U-rich motifs, which provide active sites of interaction with RNA-binding proteins), and rs2298383 (C>T substitution in a potential promoter region with a regulatory element predicted from alignment of human and other mammalian genes). ${ }^{143-146}$ Rs5751876, a synonymous mutation (normally encoded amino acid), has been associated to an earlier AAO of HD, ${ }^{147,148}$ and a recent study demonstrated a significant increase in the expression of $\mathrm{A}_{2 \mathrm{~A}} \mathrm{R}$ in the brain of HD subjects homozygous for a rs 5751876 polymorphic block (including rs35320474 and rs2298383). ${ }^{146}$ These results suggest that transcriptional dysregulation of $\mathrm{A}_{2 \mathrm{~A}} \mathrm{R}$ is associated with HD. How these data relate to the previous binding and expression studies in postmortem human brain in HD patients and in HD mouse models remains to be investigated.

Another link between the adenosine receptors and HD is the epidemiological evidence that associates the habitual consumption of caffeine with an earlier AAO of HD. ${ }^{149}$ Caffeine is a nonselective $\mathrm{A}_{1} \mathrm{R}$ and $\mathrm{A}_{2 \mathrm{~A}} \mathrm{R}$ antagonist, and it is proposed that the blockade of these receptors by caffeine may result in an increased acceleration of neurodegeneration. This could possibly be related to the fact that chronic caffeine exposure is associated with tolerance to the $A_{1} R$ but not to the $A_{2 A} R .{ }^{150}$ Studies show that high doses of $A_{2 A} R$ antagonists or global genetic $A_{2 A} R$ blockade worsen disease progression in HD models, ${ }^{151,152}$ whereas $\mathrm{A}_{2 \mathrm{~A}} \mathrm{R}$ agonists as well as $\mathrm{A}_{1} \mathrm{R}$ agonists have been shown to protect against neurodegeneration. ${ }^{151,153}$

In these animal models of HD, recently described alterations in adenosine metabolism leads to a hypotonic adenosine state (see below), and this condition could be mimicked by chronic caffeine exposure. Interestingly, Cornelis et al. described an association between the ADORA2A rs5751876 polymorphism and caffeine intake, which may link them to the HD progression. ${ }^{154}$ However, this association was not confirmed in a recent genome-wide metaanalysis of polymorphisms and habitual coffee intake. ${ }^{155}$

\section{Alterations of $A_{1} R$ function during $H D$ progression}

Data suggest that $\mathrm{A}_{1} \mathrm{R}$ stimulation has clear neuroprotective effects in animal and human models of HD. ${ }^{156,157}$ $\mathrm{A}_{1} \mathrm{R}$ activation attenuated limb dystonia and striatal degeneration in the 3 -NP model of $\mathrm{HD},{ }^{151}$ and prevented 3-NP-induced seizures in mice. ${ }^{158}$ Also, $\mathrm{A}_{1} \mathrm{R}$ blockade caused deleterious effects in malonate-induced metabolic models of HD. ${ }^{159}$

Differing results were found when investigating $A_{1} R$ binding in various transgenic rodent models of HD. In the Tg51 HD rat model, no changes in $A_{1} R$ density were observed. ${ }^{160}$ However, when the widely used symptomatic R6/2 HD mouse model was used, a decrease in cortical and 
striatal $\mathrm{A}_{1} \mathrm{R}$ antagonist binding density was observed. ${ }^{161}$ Interestingly, when comparing $\mathrm{R} 6 / 2$ mice to WT mice, despite the reduced $A_{1} R$ density, the $A_{1} R$ agonist N6Cyclopentyl-adenosine was able to further reduce synaptic transmission and glutamate release. This decrease in $\mathrm{A}_{1} \mathrm{R}$ density and its apparently increased functionality was further confirmed using $\mathrm{mHtt}$ expressing striatal cells. ${ }^{161}$ Translating these preclinical results to human HD patients, a noninvasive positron emission tomography (PET) imaging study revealed that, in symptomatic HD patients, $A_{1} R$ were significantly reduced compared with healthy non-HD subjects (see below). ${ }^{162}$

\section{Alterations of $A_{2 A} R$ during $H D$ progression}

The first evidence of $\mathrm{A}_{2 \mathrm{~A}} \mathrm{R}$ downregulation in HD was found in tissue sections of the human brain using autoradiography, ${ }^{163}$ and was later confirmed in the basal ganglia of $\mathrm{HD}$ patients in early, intermediate, and late stages of the disease. ${ }^{6}$ Downregulation of $\mathrm{A}_{2 \mathrm{~A}} \mathrm{R}$ has been reported in HD patients that have not yet displayed any motor dysfunction, ${ }^{6}$ and in animal models before any significant neuronal loss has occurred. ${ }^{152,160,164-166}$

Animal and cell models of HD have been fundamental in identifying the molecular mechanisms by which $\mathrm{mHtt}$ causes a reduction in the expression of $\mathrm{A}_{2 \mathrm{~A}} \mathrm{R}$. Most of these models clearly show $\mathrm{A}_{2 \mathrm{~A}} \mathrm{R}$ downregulation at the protein and transcription level, but there are conflicting results when tested in the H46, YAC72, and Tg51 transgenic models. ${ }^{153,164,167-171}$

Aggregated mHtt causes changes in gene expression profiles leading to specific protein-protein interactions with several transcription factors, ${ }^{172-175}$ while $\mathrm{mHtt}$ does not change gene expression relating to cytoskeleton proteins, enzymes of metabolism, mitochondrial proteins, and caspases. ${ }^{164,176}$ Chiang et al. found that $\mathrm{mHtt}$ expression significantly reduced the transcript levels of endogenous $\mathrm{A}_{2 \mathrm{~A}} \mathrm{R}$ in PC12 cells and striatal neurons in culture. ${ }^{168}$ They identified that cells expressing $\mathrm{mHtt}$ have an atypical C-AMP response element-binding protein $(\mathrm{CREB})$ responsive element site located in the core promoter of the $\mathrm{A}_{2 \mathrm{~A}} \mathrm{R}$ gene that prevents the binding of CREB, and thus suppresses the core promoter activity of the $\mathrm{A}_{2 \mathrm{~A}} \mathrm{R}$ gene. Interestingly, stimulation of the $\mathrm{A}_{2 \mathrm{~A}} \mathrm{R}$ restored normal $\mathrm{CREB}$ binding and reduced the aggregation caused by the mHtt protein. ${ }^{168}$

The length of poly(Q)-expanded Htt appears to be critical for the downregulation of the $\mathrm{A}_{2 \mathrm{~A}} \mathrm{R}$ transcript, and it has been hypothesized that transcriptional dysfunctions only occur in the presence of a short N-terminal fragment ( $<171$ amino acids) of mHtt. No reduction in the expression of $\mathrm{A}_{2 \mathrm{~A}} \mathrm{R}$ and other $\mathrm{mHtt}$ sensitive genes were seen in either a model that expresses an extended $\mathrm{N}$-terminal fragment (HD46), or in a model that expresses a full-length mHtt (YAC72). ${ }^{167}$ DNA methylation (5methylcytosine, $5 \mathrm{mC}$, and 5-hydroxymethylcytosine,
5hmC), an important mechanism for epigenetic silencing that regulates basal $\mathrm{A}_{2 \mathrm{~A}} \mathrm{R}$ level in the human brain, ${ }^{177}$ has been proposed to be a key mechanism for the reduced striatal $\mathrm{A}_{2 \mathrm{~A}} \mathrm{R}$ levels observed in the brains of HD patients and in R6/1 and R6/2 mice. ${ }^{170,178,179}$ In their study, VillarMenéndez et al. found an increase in $5 \mathrm{mC}$ levels and a reduction in $5 \mathrm{hmC}$ levels in the $5^{\prime}$ untranslated region of the $\mathrm{A}_{2 \mathrm{~A}} \mathrm{R}$ gene, and these findings were closely associated with the downregulation of the $\mathrm{A}_{2 \mathrm{~A}} \mathrm{R}$ transcript seen in $\mathrm{R} 6 / 2$ mice and in the putamen of HD patients. ${ }^{170}$ These results suggest that using strategies that modulate $\mathrm{A}_{2 \mathrm{~A}} \mathrm{R}$ expression could be a new approach to treating $\mathrm{HD}$.

In addition to studies showing $\mathrm{A}_{2 \mathrm{~A}} \mathrm{R}$ reduction in $\mathrm{HD}$, others have reported that as $\mathrm{HD}$ progresses the presence of mHtt can abnormally amplify signaling of the $\mathrm{A}_{2 \mathrm{~A}} \mathrm{R}$. Varani et al. reported an amplification of $\mathrm{A}_{2 \mathrm{~A}} \mathrm{R}$-mediated adenylyl cyclase stimulation in striatal-derived cells engineered to express $\mathrm{mHtt},{ }^{180}$ a result confirmed in the striatum of R6/2 mice. ${ }^{153,169}$ This amplification of $\mathrm{A}_{2 \mathrm{~A}} \mathrm{R}$ signaling was also found in peripheral blood cells in HD subjects, where overstimulation of $\mathrm{A}_{2 \mathrm{~A}} \mathrm{R}$-mediated cAMP production was associated with an aberrant increase in $\mathrm{A}_{2 \mathrm{~A}} \mathrm{R}$ function and density. ${ }^{181}$

$\mathrm{A}_{2 \mathrm{~A}} \mathrm{R}$ density in blood platelets has been shown to correlate with the age of onset and CAG repeat expansion in HD patients. ${ }^{182}$ These data suggest that further studies investigating abnormal $\mathrm{A}_{2 \mathrm{~A}} \mathrm{R}$ signaling in peripheral blood cells are needed to validate using this receptor target as a potential biomarker for disease prognosis and drug efficacy.

\section{PET imaging for adenosine receptor occupancy in $H D$}

PET is a functional imaging technique that is used to observe receptor binding capacity in the body and can aid in the diagnosis of many neurological diseases, including HD. ${ }^{183}$ Different radiotracers have been used with PET to measure brain metabolism, dopaminergic function, neuro-inflammation, phosphodiesterases, and other targets in HD. ${ }^{183}$ However, few adenosine analog radiotracers have been developed and employed to noninvasively image $A_{1} R$ and $A_{2 A} R$ occupancy.

One such radio-ligand that can be used to image the $\mathrm{A}_{1} \mathrm{R}$ in vivo is $\left[{ }^{18} \mathrm{~F}\right] \mathrm{CPFPX} .{ }^{184-186} \mathrm{~A}$ cross-sectional study using $\left[{ }^{18} \mathrm{~F}\right] \mathrm{CPFPX}$ and MRI was performed to assess differences in $\mathrm{A}_{1} \mathrm{R}$ density between controls and HD patients at different stages of the disease progression ("premanifest patients far from the onset of predicted symptoms", "premanifest patients near the onset of predicted symptoms", and "manifest patients"). ${ }^{162}$ In this study, $\left[{ }^{18} \mathrm{~F}\right] \mathrm{CPFPX}$ binding in the caudate of "manifest HD patients" was reduced by $25 \%$, and $\left[{ }^{18} \mathrm{~F}\right] \mathrm{CPFPX}$ binding in the thalamus of "premanifest patients far from the onset of predicted symptoms" was $31 \%$ higher than health controls. Interestingly, thalamic $\left[{ }^{18} \mathrm{~F}\right] \mathrm{CPFPX}$ binding between "premanifest patients near the onset of predicted symptoms" and healthy controls was similar. These data 
suggest that $A_{1} R$ switch from upregulation to downregulation as HD progresses. This study reveals the importance of $\mathrm{A}_{1} \mathrm{R}$ in the pathology of $\mathrm{HD}$, and shows that $\left[{ }^{18} \mathrm{~F}\right] \mathrm{CPFPX}$ and PET can be a useful tool to explore $A_{1} R$ interactions in preclinical and clinical trials. ${ }^{162}$

Radio-ligands developed and tested to image $\mathrm{A}_{2 \mathrm{~A}} \mathrm{R}$ antagonists, in particular, the xanthine ligands $\left[{ }^{11} \mathrm{C}\right] \mathrm{TMSX}$, $\left[{ }^{11} \mathrm{C}\right] \mathrm{KF} 17837,\left[{ }^{11} \mathrm{C}\right] \mathrm{TMSX},\left[{ }^{11} \mathrm{C}\right] \mathrm{KF} 21213,\left[{ }^{11} \mathrm{C}\right] \mathrm{KF} 19631$, and $\left[{ }^{11} \mathrm{C}\right] \mathrm{KW} 6002$, have not been particularly useful for molecular imaging due to their low signal to noise ratio and high degree of nonspecific binding. ${ }^{187}$ In general, radio-ligands that lack the xanthine structure appear to have better specificity for the $\mathrm{A}_{2 \mathrm{~A}} \mathrm{R}$ subtype and allow quantitative imaging of $\mathrm{A}_{2 \mathrm{~A}} \mathrm{R}$ in the mammalian striatum, but even these are less effective at imaging other areas of the brain. ${ }^{188}\left[{ }^{11} \mathrm{C}\right] \mathrm{SCH} 442416$ was the first non-Xanthine ligand that was suitable for mapping of $\mathrm{A}_{2 \mathrm{~A}} \mathrm{R}$ using PET. ${ }^{189}$ Recently, $\left[{ }^{11} \mathrm{C}\right.$ ]preladenant has been used to quantify $\mathrm{A}_{2 \mathrm{~A}} \mathrm{R}$ binding sites in the rat brain. It displayed high uptake in the striatum, and low, homogenous uptake in all extra-striatal regions, a binding profile that corresponds to the known $\mathrm{A}_{2 \mathrm{~A}} \mathrm{R}$ expression in the rat brain. ${ }^{190}$ Although $\left[{ }^{11} \mathrm{C}\right]$ preladenant is tolerated, and has been used in both humans and monkeys to study $\mathrm{A}_{2 \mathrm{~A}} \mathrm{R}$ expression in the brain, ${ }^{191,192}$ very few PET imagining studies investigating the role of $\mathrm{A}_{2 \mathrm{~A}} \mathrm{R}$ in $\mathrm{HD}$ pathology have been performed.

Finally, in the QA model of HD, that results in a loss of striato-pallidal GABAergic enkephalin neurons, the binding potential of $\left[{ }^{11} \mathrm{C}\right] \mathrm{KF} 18446$ in the striatum and globus pallidus was reduced by $25 \% .^{165}$ This amount of loss is similar to that seen when $\left[{ }^{11} \mathrm{C}\right]$ raclopride is used to measure the binding potential of $\mathrm{D}_{2} \mathrm{R} .{ }^{165}$ As new and more suitable $\mathrm{A}_{2 \mathrm{~A}} \mathrm{R}$ radiotracers are developed, more detailed PET studies investigating the role of $\mathrm{A}_{2 \mathrm{~A}} \mathrm{R}$ in HD can be performed.

\section{Alterations in striatal adenosine tone in $H D$}

In the Tg51 rat model of HD there is a slower disease progression as compared to other animal models, and this allows for evaluating possible biomarkers that might be present during the initial phases of HD. ${ }^{193}$ Using this model, we found that there were alterations in the adenosine system that were independent of alterations in $\mathrm{A}_{2 \mathrm{~A}} \mathrm{R}$ expression. ${ }^{171}$ Analyzing the function of pre- and postsynaptic $A_{2 A} R$ in the striatum, it was originally believed that during the initial stages of $\mathrm{HD}$, the postsynaptic striatal $\mathrm{A}_{2 \mathrm{~A}} \mathrm{R}$ were selectively and functional impaired. ${ }^{166}$ This was based on the observation that $\mathrm{A}_{2 \mathrm{~A}} \mathrm{R}$ antagonists were unable to produce locomotor activity in this model, while their ability to modulate cortical-striatal neurotransmission remained unchanged. ${ }^{194}$ It was assumed that this difference was due to the downregulation of $\mathrm{A}_{2 \mathrm{~A}} \mathrm{R}$ that is seen in both human and animal models of HD. A pharmacological characterization of the $\mathrm{Tg} 51$ however, revealed that postsynaptic $\mathrm{A}_{2 \mathrm{~A}} \mathrm{R}$ function was not altered at all. After the administration of an $\mathrm{A}_{2 \mathrm{~A}} \mathrm{R}$ agonist, no difference in postsynaptic-dependent locomotor depression was seen when Tg51 rats were compared to their WT littermates. ${ }^{171}$ More convincingly, no difference in the number of striatal $\mathrm{A}_{2 \mathrm{~A}} \mathrm{R}$ sites or affinity was seen when WT rats were compared with either Tg51 homozygous or heterozygous rats. ${ }^{171}$ Together, the agonist effect, and the lack of antagonist effect suggested a low adenosinergic tone, resulting in a decreased ability of endogenous adenosine to activate the postsynaptic $\mathrm{A}_{2 \mathrm{~A}} \mathrm{R}$. This would explain the preserved ability of $\mathrm{A}_{2 \mathrm{~A}} \mathrm{R}$ antagonists to block cortical-striatal transmission, because presynaptic activation of $\mathrm{A}_{2 \mathrm{~A}} \mathrm{R}$ is dependent on a phasic increase of extracellular adenosine. In fact, we showed a reduction in extracellular adenosine levels in the striatum of Tg51 rats and also of zQ175 knock-in mice, ${ }^{171}$ a recently developed transgenic animal model of HD. ${ }^{195}$ Unlike the Tg51 rats, we observed a downregulation of $\mathrm{A}_{2 \mathrm{~A}} \mathrm{R}$ in the $\mathrm{zQ} 175$ mice. ${ }^{171}$

It is well accepted that under physiological conditions, the main source of extracellular adenosine production is the release of ATP by astroglial vesicles. ${ }^{127}$ Extracellular ATP is rapidly converted to adenosine by a series of ectonucleotidases and extracellular levels of adenosine (adenosinergic tone) is maintained by the equilibrative transporter's and the astrocytic adenosine kinase's (ADK) ability to uptake and metabolize adenosine, respectively. ${ }^{128,196}$ In mammals, there are two types of nucleoside transporters: bidirectional, equilibrative transporters that are driven by chemical gradients, and unidirectional, concentration transporters that are driven by sodium electrochemical gradients. ${ }^{197}$ Adenosine uptake in the brain is mostly facilitated by the equilibrative nucleoside transporters, and when these transporters are blocked pharmacologically, adenosine accumulates in the extracellular space $^{128,197,198}$ Of the four equilibrative transporters identified (ENT1, ENT2, ENT3, and ENT4), ENT1 and ENT2 are the ones mostly present in the brain, expressed by both neurons and astrocytes. ${ }^{197}$ Studies suggest that because of its dependence on glutamate receptor activation, the ENT1 plays a more prominent role in determining the concentration of extracellular adenosine in the brain. ${ }^{199,200}$

Using the ENT1 selective inhibitor $\left[{ }^{3} \mathrm{H}\right]-\mathrm{S}-(4-N i t r o-$ benzyl)-6-thioinosine $\left(\left[{ }^{3} \mathrm{H}\right] \mathrm{NBTI}\right)$, we found an upregulation of the ENT1 transporter in zQ175 mice. ${ }^{171}$ Also, the ENT1 gene transcript (SLC29A1) was upregulated in HD patients during early stages of neuropathological severity, but not in those with higher stages of severity, relative to controls. ${ }^{171}$ In a more recent study, we found that cerebral spinal fluid (CSF) adenosine levels were significantly lower in HD patients and CSF concentrations of ATP were inversely correlated with the number of CAG repeats. ${ }^{201}$ Also, the disease duration of these HD patients was negatively correlated to the adenosine/ ATP ratio. ${ }^{201}$ These data suggest that adenosine levels may constitute another biomarker that can be used for diagnosing and treating HD. 


\section{Adenosine Neurotransmission as a Therapeutic Target in HD}

Targeting $A_{2 A} R$ in chemical- and lesion-induced $H D$ models

Effective tools to study the neurodegenerative effects seen in HD are chemical- and lesion-induced rodent models. Injecting the NMDA receptor agonist QA into the striatum or systemically administering the mitochondrial toxin 3-NP can mimic the anatomical and behavioral deficits seen in HD. These manipulations can also produce direct and indirect excitotoxicity and trigger the selective loss of MSNs in the striatum similar to that seen in HD. ${ }^{26,202-205}$ Likewise, intra-striatal injections of malonate, a competitive inhibitor of succinate dehydrogenase, can produce significant lesions in the striatum like those present in HD patients. ${ }^{206-208}$

Using these models, it has been shown that administering various $\mathrm{A}_{2 \mathrm{~A}} \mathrm{R}$ antagonists (DMPX, SCH58261, ZM241385, ST1535, MSX-3, and CSC) can have multiple beneficial effects. $\mathrm{A}_{2 \mathrm{~A}} \mathrm{R}$ antagonism can reduce striatal degeneration (atrophy), normalize EEG patterns, and normalize motor activity. It can also improve the loss of GABA content and lower the outflow of glutamate, all of which can increase the life span in HD patients. ${ }^{40,41,159,209-213}$ In contrast, the $\mathrm{A}_{2 \mathrm{~A}} \mathrm{R}$ agonist (CGS21680) was shown to increase the 3-NP-induced striatal lesion size. ${ }^{40}$

Opposing results were found when 3-NP-evoked striatal damage was assessed in $\mathrm{A}_{2 \mathrm{~A}} \mathrm{R}$-null mice. Global $\mathrm{A}_{2 \mathrm{~A}} \mathrm{R}$ knock-out mice showed opposite effects on the 3-NP-induced neurological deficit behaviors and striatal damage at different dosages, ${ }^{40,209,214}$ and the selective depletion of $\mathrm{A}_{2 \mathrm{~A}} \mathrm{R}$ in forebrain neurons did not contribute to the 3-NP-evoked striatal damage. ${ }^{214}$ However, the selective removal of $\mathrm{A}_{2 \mathrm{~A}} \mathrm{R}$ in bone marrow-derived cells caused the enhanced 3-NP-induced striatal damage in global $\mathrm{A}_{2 \mathrm{~A}} \mathrm{R}$ knock-out mice to return. These finding argue against the importance of $\mathrm{A}_{2 \mathrm{~A}} \mathrm{R}$-mediated glutamate release in 3 -NP-induced striatal damage, ${ }^{214}$ suggesting the potential involvement of diverse cell types. The possible role of $\mathrm{A}_{2 \mathrm{~A}} \mathrm{R}$ in controlling non-neuronal cells (e.g., glia) might also contribute to the function of $\mathrm{A}_{2 \mathrm{~A}} \mathrm{R}$ in the brain. Inactivation of $\mathrm{A}_{2 \mathrm{~A}} \mathrm{R}$ appears to be beneficial in the chemical- and lesion-induced HD models, but further evaluation is required.

\section{Targeting $A_{1} R$ in phenotypic HD models}

Targeting the $\mathrm{A}_{1} \mathrm{R}$ for the treatment of $\mathrm{HD}$ has been mostly under evaluated. Using the 3-NP mouse model of $\mathrm{HD}$, we observed that acute administration of the $\mathrm{A}_{1} \mathrm{R}$ agonist adenosine amine congener reduced the size of 3-NPinduced striatal lesions, limited striatal degeneration, and prevented the development of the hind limb dystonia that is present after 3-NP treatment. ${ }^{151}$ Other studies also show evidence that $A_{1} R$ activation has protective effects. The administration of an $A_{1} R$ agonist was able to prevent 3-NP-induced seizures in mice, ${ }^{158}$ and $\mathrm{A}_{1} \mathrm{R}$ block- ade potentiated the damage to dopaminergic neurons caused by an intra-striatal infusion of malonate. ${ }^{159}$ The protective effects of $A_{1} R$ agonists can be attributed to their ability to reduce glutamate release by activating presynaptic receptors in the striatum. ${ }^{151}$ The potential cardiovascular side effects of $\mathrm{A}_{1} \mathrm{R}$ activation has limited its investigation as a potential therapeutic for treating $\mathrm{HD},{ }^{215}$ but new studies targeting basal levels of adenosine (see below) might lead researchers to reconsider the $A_{1} R$ as a potential direct or indirect target in HD treatment.

\section{Targeting $A_{2 A} R$ in phenotypic HD models}

The first genetic mouse model of HD was developed and characterized two decades ago. ${ }^{178}$ Since then, more than 30 genetic mouse models of HD are now available from various sources. ${ }^{216}$ Multiple genetic models of HD including transgenic, conditional transgenic, and knock-in mice have been created and are being used to study various stages of HD progression. ${ }^{217-220}$

One such model that has been useful in studying the involvement of $\mathrm{A}_{2 \mathrm{~A}} \mathrm{R}$ in the pathogenesis of $\mathrm{HD}$ is the R6/2 mouse model. These mice express the exon 1 of the human huntingtin gene, ${ }^{178}$ and quickly show a progression of many HD symptoms, including motor impairment, aggregate formation, and body weight loss. ${ }^{176,221}$ Pharmacological treatments with $\mathrm{A}_{2 \mathrm{~A}} \mathrm{R}$ agonists have beneficial effects in R6/2 mice. Mice chronically treated with CGS21680 had reduced mHtt aggregate accumulation and had lowered enhancing proteasome activity, while the administration of T1-11 in R6/2 mice enhanced the performance on the rota-rod test, and enhanced proteasome activity. $36,120,153,63,222-225$

Interestingly, the blockade of $\mathrm{A}_{2 \mathrm{~A}} \mathrm{R}$ also has beneficial effects in R6/2 mice. Studies showed that the administration of the $\mathrm{A}_{2 \mathrm{~A}} \mathrm{R}$ antagonist SCH58261 in R6/2 mice reduced glutamate and adenosine outflow, normalized the alteration in emotional response, and reduced NMDAinduced toxicity, ${ }^{226,227}$ but had no effect on locomotor capability. ${ }^{226,228}$ Genetic and pharmacological inactivation of $\mathrm{A}_{2 \mathrm{~A}} \mathrm{R}$ reduced working memory deficits in $\mathrm{R} 6 / 2$ mice, ${ }^{229}$ and the combined blockade of $D_{1} R$ and $A_{2 A} R$ improved cognitive dysfunction in a different transgenic HD mouse model $(R 6 / 1){ }^{230}$ Taken together, these results suggest that $\mathrm{A}_{2 \mathrm{~A}} \mathrm{R}$ blockade may be able to reverse the cognitive impairment that develops in these HD mice.

While $\mathrm{A}_{2 \mathrm{~A}} \mathrm{R}$ blockade appears to aid cognitive function in $\mathrm{HD}$, its effects on motor dysfunction is less clear. In the N171-82Q HD model, mHtt is expressed only in the neurons. These mice develop behavioral abnormalities including loss of coordination, tremors, hypokinesis, and abnormal gait, before dying prematurely. When the $\mathrm{A}_{2 \mathrm{~A}} \mathrm{R}$ is genetically deleted, by crossing $\mathrm{A}_{2 \mathrm{~A}} \mathrm{R}$ knockout mice with the N171-82Q, the life expectancy of these mice decreases, and their motor impairments are more severe when compared to the N171-82Q mice. ${ }^{152}$ These data are 
in agreement with the earlier studies showing that activation of $\mathrm{A}_{2 \mathrm{~A}} \mathrm{R}$ improved motor function in the R6/2 HD mice, ${ }^{153}$ and might raise concerns about investigating $\mathrm{A}_{2 \mathrm{~A}} \mathrm{R}$ antagonists as a treatment in human HD patients. Given that activation of $\mathrm{A}_{2 \mathrm{~A}} \mathrm{R}$ has a beneficial effect on the motor impairment seen in HD mouse models, and inactivation of $\mathrm{A}_{2 \mathrm{~A}} \mathrm{R}$ in some models improves cognitive function, the symptom-specific effects of $\mathrm{A}_{2 \mathrm{~A}} \mathrm{R}$ treatments needs to be further investigated.

\section{Targeting ENT1 in phenotypic HD models}

Because ENT1 is upregulated while adenosine tone is reduced in both animal models and HD patients, it is proposed that ENT1 could constitute a new therapeutic target that may delay the progression of HD. Pharmacological blockade with the low affinity ENT1 inhibitor JMF $1907^{231}$ or genetic blockade of ENT (global ENT1 knockout) led to a significant increase in the mean survival time in the R6/2 mouse model of HD. ${ }^{201}$ In the same study, there was also an increase in the expression and activity of both ENT1 and ENT2. ${ }^{201}$ More support for this hypothesis comes from the fact that there is a decrease in tonic striatal adenosine levels in both $\mathrm{R} 6 / 2$ mice and in the knock-in $\mathrm{Hdh}(\mathrm{CAG}) 150$ mouse. $^{232}$

In two genetic animal models, the expression of ectonucleotidases and ADK were also analyzed. ADK transcript was upregulated only in R6/2 mice, ${ }^{201}$ indicating that equilibrative transporters are more likely to represent a key pathogenetic mechanism in HD. This suggests that ENT1 and less selective ENT1/ENT2 inhibitors should be considered as new therapeutic drugs that may decrease the progression of HD.

JMF 1907 belongs to a group of multifunctional adenosine compounds that are both ENT1 inhibitors and $\mathrm{A}_{2 \mathrm{~A}} \mathrm{R}$ agonists, and although it readily crosses the blood-brain barrier, it is still under preclinical evaluation. ${ }^{201,231}$ Given that inhibitors of ENT1 such as dipyridamole, ticagrelor, or dilazep are already being used to treat different pathological conditions related to vascular relaxation and platelet aggregation, and that the ENT1 inhibiting nonsteroidal anti-inflammatory drug sulindac sulfide is being used as an anti-inflammatory, it has been suggested that these compounds should be clinically studied in HD patients to evaluate their ability to delay the progression or the $\mathrm{AAO}$ of $\mathrm{HD}$, even though some of these drugs have low brain penetrability. ${ }^{233}$

The classical reserpinized mice model is a method that can be used to study specific antagonistic interactions between adenosine and dopamine receptor ligands and it led to the discovery of the $\mathrm{A}_{2 \mathrm{~A}} \mathrm{R}-\mathrm{D}_{2} \mathrm{R}$ and $\mathrm{A}_{1} \mathrm{R}-\mathrm{D}_{1} \mathrm{R}$ heteromers. ${ }^{234,235}$ Using this method, we evaluated dipyridamole's ability to decrease the locomotor activation induced by dopamine receptor agonists. At a minimal dose of $30 \mathrm{mg} / \mathrm{kg}$ administered systemically, dipyridamole significantly decreased the locomotor-activating effect of equipotent doses of selective $D_{1} R$ and $D_{2} R$ agonists and this depressant effect was completely counteracted by caffeine. ${ }^{236}$ These results suggest that basal extracellular levels of adenosine in the striatum were increased following the systemic administration of dipyridamole and this increase in adenosine levels could explain the observed ability of dipyridamole to depress both $\mathrm{D}_{1} \mathrm{R}$ and $\mathrm{D}_{2} \mathrm{R}$ agonist-mediated locomotor activation in the reserpinized mice. The fact that this depressant effect was counteracted by caffeine, a non-selective adenosine antagonist, suggests that an increase in basal levels of adenosine may exert influence on both the tonic activation of pre- and postsynaptic $A_{1} R$ and postsynaptic $A_{2 A} R$. Since the activation of presynaptic $A_{1} R$ leads to a decrease in glutamate release, therapeutics that can increase tonic levels of adenosine may be a beneficial treatment in patients with HD

\section{Concluding Remarks}

Many genetic, epidemiological, and experimental studies suggest that adenosine receptors, both $A_{1} R$ and $\mathrm{A}_{2 \mathrm{~A}} \mathrm{R}$ are linked to HD pathophysiology, although their exact involvement remains unclear. Additional investigations using specific ligands and genetic murine tools are needed to dissect the pre- and postsynaptic aspects of $\mathrm{A}_{2 \mathrm{~A}} \mathrm{R}$, and the relationship between $\mathrm{A}_{2 \mathrm{~A}} \mathrm{R}$ and $\mathrm{mHtt}$ induced glial dysfunction, which has been largely underestimated. Also, since HD is a chronically progressive disease, there are multiple mechanisms along the degenerative process that may be affected by their interactions with $A_{2 A} R$. Since $A_{2 A} R$ heteromerize with several other GPCR that are involved in HD-related striatal dysfunction and degradation including $\mathrm{D}_{2} \mathrm{R}$ and $\mathrm{A}_{1} \mathrm{R}, \mathrm{A}_{2 \mathrm{~A}} \mathrm{R}$ containing heteromers should also be considered targets for HD-related drug development. Finally, the role of $\mathrm{A}_{1} \mathrm{R}$ in $\mathrm{HD}$ pathogenesis needs to be reconsidered. The role of low adenosine tone in HD and recent studies indicating that ENT1 is upregulated in HD suggest that in addition to $A_{2 A} R, A_{1} R$ may also be a possible target for developing drugs that maybe beneficial in treating HD.

\section{Acknowledgments}

D.B. and L.B. are supported by grants from "France Alzheimer/Fondation de France," FHU VasCog Research Network and "Program d'Investissements d'Avenir" LabEx (excellence laboratory), DISTALZ (Development of Innovative Strategies for a Transdisciplinary approach to Alzheimer's disease), ANR, "Fondation pour la Recherche Médicale," Vaincre Alzheimer, "Fondation Plan Alzheimer," Inserm, CNRS, Université Lille, Lille Métropole Communauté Urbaine, Région Hauts de France, and DN2M. Y.C. and C.Y.L. are supported by the Institute of Biomedical Sciences of Academia Sinica (103Academia Sinica Investigation Award-06). M.R.D. and P.P. are supported by grants from the Italian Ministry 
of Health. W.R. and S.F. are supported by the intramural funds of the National Institute on Drug Abuse.

\section{Author Disclosure Statement}

No competing financial interests exist.

\section{References}

1. Ross CA, Tabrizi SJ. Huntington's disease: From molecular pathogenesis to clinical treatment. Lancet Neurol. 2011;10:83-98.

2. McColgan P, Tabrizi SJ. Huntington's disease: A clinical review. Eur J Neurol. 2018;25:24-34.

3. Vonsattel JP, DiFiglia M. Huntington disease. J Neuropathol Exp Neurol. 1998;57:369-384.

4. Ferré S, O'Connor WT, Fuxe K, Ungerstedt U. The striopallidal neuron: A main locus for adenosinedopamine interactions in the brain. J Neurosci. 1993; 13:5402-5406.

5. Schiffmann SN, Vanderhaeghen JJ. Adenosine A2 receptors regulate the gene expression of striatopallidal and striatonigral neurons. J Neurosci. 1993;13:1080-1087.

6. Glass M, Dragunow M, Faull RL. The pattern of neurodegeneration in Huntington's disease: A comparative study of cannabinoid, dopamine, adenosine and $\operatorname{GABA}(\mathrm{A})$ receptor alterations in the human basal ganglia in Huntington's disease. Neuroscience. 2000;97:505-519.

7. Deng YP, Albin RL, Penney JB, Young AB, Anderson $\mathrm{KD}$, Reiner A. Differential loss of striatal projection systems in Huntington's disease: A quantitative immunohistochemical study. J Chem Neuroanat. 2004;27:143-164.

8. The Huntington's Disease Collaborative Research Group. A novel gene containing a trinucleotide repeat that is expanded and unstable on Huntington's disease chromosomes. Cell. 1993;72:971-983.

9. Walker FO. Huntington's disease. Lancet. 2007;369: 218-228.

10. Bantubungi K, Blum D. Mechanisms of neuronal death in Huntington's disease. First part: General considerations and histopathological features. Rev Med Brux. 2007;28:413-421.

11. Bantubungi K, Blum D. Mechanisms of neuronal death in Huntington's disease. Second part: Therapeutic challenges]. Rev Med Brux. 2007;28:487-494.

12. Popoli P, Blum D, Domenici MR, Burnouf S, Chern Y. A critical evaluation of adenosine A2A receptors as potentially "druggable" targets in Huntington's disease. Curr Pharm Des. 2008;14:1500-1511.

13. Zuccato C, Valenza M, Cattaneo E. Molecular mechanisms and potential therapeutical targets in Huntington's disease. Physiol Rev. 2010;90:905-981.

14. Trottier Y, Devys D, Imbert G, et al. Cellular localization of the Huntington's disease protein and discrimination of the normal and mutated form. Nat Genet 1995; 10:104-110.

15. Gourfinkel-An I, Cancel G, Trottier Y, et al. Differential distribution of the normal and mutated forms of huntingtin in the human brain. Ann Neurol. 1997;42:712-719.

16. Shin JY, Fang ZH, Yu ZX, Wang CE, Li SH, Li XJ. Expression of mutant huntingtin in glial cells contributes to neuronal excitotoxicity. J Cell Biol. 2005; 171: 1001-1012.
17. Saudou F, Humbert S. The biology of huntingtin. Neuron. 2016:89:910-926.

18. Dragatsis I, Efstratiadis A, Zeitlin S. Mouse mutant embryos lacking huntingtin are rescued from lethality by wild-type extraembryonic tissues. Development. 1998;125:1529-1539.

19. Godin JD, Colombo K, Molina-Calavita M, et al. Huntingtin is required for mitotic spindle orientation and mammalian neurogenesis. Neuron. 2010;67:392-406.

20. Barnat $M$, Le Friec J, Benstaali C, Humbert $S$. Huntingtin-mediated multipolar-bipolar transition of newborn cortical neurons is critical for their postnatal neuronal morphology. Neuron. 2017;93:99-114.

21. Colin E, Zala D, Liot G, et al. Huntingtin phosphorylation acts as a molecular switch for anterograde/ retrograde transport in neurons. EMBO J. 2008;27: 2124-2134.

22. Gauthier LR, Charrin BC, Borrell-Pagès M, et al. Huntingtin controls neurotrophic support and survival of neurons by enhancing BDNF vesicular transport along microtubules. Cell. 2004;118:127-138.

23. Zuccato C, Cattaneo E. Brain-derived neurotrophic factor in neurodegenerative diseases. Nat Rev Neurol. 2009;5:311-322.

24. Stopschinski BE, Diamond MI. The prion model for progression and diversity of neurodegenerative diseases. Lancet Neurol. 2017;16:323-332.

25. Stack EC, Dedeoglu A, Smith KM, et al. Neuroprotective effects of synaptic modulation in Huntington's disease R6/2 mice. J Neurosci. 2007;27:12908-12915.

26. Brouillet E, Jacquard C, Bizat N, Blum D. 3-Nitropropionic acid: A mitochondrial toxin to uncover physiopathological mechanisms underlying striatal degeneration in Huntington's disease. J Neurochem. 2005;95: 1521-1540.

27. Jacquard C, Trioulier Y, Cosker F, et al. Brain mitochondrial defects amplify intracellular $[\mathrm{Ca} 2+]$ rise and neurodegeneration but not $\mathrm{Ca} 2+$ entry during NMDA receptor activation. FASEB J. 2006;20:1021-1023.

28. Fan MM, Raymond LA. N-methyl-D-aspartate (NMDA) receptor function and excitotoxicity in Huntington's disease. Prog Neurobiol. 2007;81:272-293.

29. Lievens JC, Woodman B, Mahal A, et al. Impaired glutamate uptake in the R6 Huntington's disease transgenic mice. Neurobiol Dis. 2001;8:807-821.

30. Bradford J, Shin JY, Roberts M, Wang CE, Li XJ, Li S. Expression of mutant huntingtin in mouse brain astrocytes causes age-dependent neurological symptoms. Proc Natl Acad Sci USA. 2009;106:22480-22485.

31. Faideau M, Kim J, Cormier K, et al. In vivo expression of polyglutamine-expanded huntingtin by mouse striatal astrocytes impairs glutamate transport: A correlation with Huntington's disease subjects. Hum Mol Genet. 2010;19:3053-3067.

32. Chen N, Luo T, Wellington C, et al. Subtype-specific enhancement of NMDA receptor currents by mutant huntingtin. J Neurochem. 1999;72:1890-1898.

33. Sun Y, Savanenin A, Reddy PH, Liu YF. Polyglutamineexpanded huntingtin promotes sensitization of N-methylD-aspartate receptors via post-synaptic density 95 . J Biol Chem. 2001;276:24713-24718.

34. Zeron MM, Hansson $\mathrm{O}$, Chen $\mathrm{N}$, et al. Increased sensitivity to N-methyl-D-aspartate receptor-mediated excitotoxicity 
in a mouse model of Huntington's disease. Neuron. 2002; 33:849-860.

35. Cepeda C, Ariano MA, Calvert CR, et al. NMDA receptor function in mouse models of Huntington disease. J Neurosci Res. 2001;66:525-539.

36. Ferrante A, Martire A, Armida M, et al. Influence of CGS 21680, a selective adenosine A(2A) receptor agonist, on NMDA receptor function and expression in the brain of Huntington's disease mice. Brain Res. 2010; 1323:184-191.

37. Martire A, Ferrante A, Potenza RL, et al. Remodeling of striatal NMDA receptors by chronic $\mathrm{A}(2 \mathrm{~A})$ receptor blockade in Huntington's disease mice. Neurobiol Dis. 2010;37:99-105.

38. Shehadeh J, Fernandes HB, Zeron Mullins MM, et al. Striatal neuronal apoptosis is preferentially enhanced by NMDA receptor activation in YAC transgenic mouse model of Huntington disease. Neurobiol Dis. 2006;21:392-403.

39. Milnerwood AJ, Gladding CM, Pouladi MA, et al. Early increase in extrasynaptic NMDA receptor signaling and expression contributes to phenotype onset in Huntington's disease mice. Neuron. 2010;65:178-190.

40. Blum D, Galas MC, Pintor A, et al. A dual role of adenosine A2A receptors in 3-nitropropionic acid-induced striatal lesions: Implications for the neuroprotective potential of A2A antagonists. J Neurosci. 2003;23:53615369.

41. Popoli P, Pintor A, Domenici MR, et al. Blockade of striatal adenosine $\mathrm{A} 2 \mathrm{~A}$ receptor reduces, through a presynaptic mechanism, quinolinic acid-induced excitotoxicity: Possible relevance to neuroprotective interventions in neurodegenerative diseases of the striatum. J Neurosci. 2002;22:1967-1975.

42. Beal MF, Kowall NW, Ellison DW, Mazurek MF, Swartz KJ, Martin JB. Replication of the neurochemical characteristics of Huntington's disease by quinolinic acid. Nature. 1986;321:168-171.

43. Guidetti P, Luthi-Carter RE, Augood SJ, Schwarcz R. Neostriatal and cortical quinolinate levels are increased in early grade Huntington's disease. Neurobiol Dis. 2004;17:455-461.

44. Guidetti P, Bates GP, Graham RK, et al. Elevated brain 3-hydroxykynurenine and quinolinate levels in Huntington disease mice. Neurobiol Dis. 2006;23:190-197.

45. Brouillet E, Conde F, Beal MF, Hantraye P. Replicating Huntington's disease phenotype in experimental animals. Prog Neurobiol. 1999;59:427-468.

46. Liot G, Valette J, Pépin J, Flament J, Brouillet E. Energy defects in Huntington's disease: Why "in vivo" evidence matters. Biochem Biophys Res Commun. 2017; 483:1084-1095.

47. Jenkins BG, Rosas HD, Chen YC, et al. 1H NMR spectroscopy studies of Huntington's disease: Correlations with CAG repeat numbers. Neurology. 1998;50:13571365.

48. Browne SE, Bowling AC, MacGarvey U, et al. Oxidative damage and metabolic dysfunction in Huntington's disease: Selective vulnerability of the basal ganglia. Ann Neurol. 1997;41:646-653.

49. Gu M, Gash MT, Mann VM, Javoy-Agid F, Cooper JM, Schapira AH. Mitochondrial defect in Huntington's disease caudate nucleus. Ann Neurol. 1996;39:385-389.
50. Tabrizi SJ, Cleeter MW, Xuereb J, Taanman JW, Cooper JM, Schapira AH. Biochemical abnormalities and excitotoxicity in Huntington's disease brain. Ann Neurol. 1999;45:25-32.

51. Benchoua A, Trioulier Y, Zala D, et al. Involvement of mitochondrial complex II defects in neuronal death produced by N-terminus fragment of mutated huntingtin. Mol Biol Cell. 2006;17:1652-1663.

52. Benchoua A, Trioulier Y, Diguet E, et al. Dopamine determines the vulnerability of striatal neurons to the $\mathrm{N}$-terminal fragment of mutant huntingtin through the regulation of mitochondrial complex II. Hum Mol Genet. 2008; 17:1446-1456.

53. Panov AV, Gutekunst CA, Leavitt BR, et al. Early mitochondrial calcium defects in Huntington's disease are a direct effect of polyglutamines. Nat Neurosci. 2002;5: 731-736.

54. Kim J, Moody JP, Edgerly CK, et al. Mitochondrial loss, dysfunction and altered dynamics in Huntington's disease. Hum Mol Genet. 2010;19:3919-3935.

55. Weydt P, Pineda VV, Torrence AE, et al. Thermoregulatory and metabolic defects in Huntington's disease transgenic mice implicate PGC-1alpha in Huntington's disease neurodegeneration. Cell Metab. 2006;4:349362.

56. Shirendeb U, Reddy AP, Manczak M, et al. Abnormal mitochondrial dynamics, mitochondrial loss and mutant huntingtin oligomers in Huntington's disease: Implications for selective neuronal damage. Hum Mol Genet. 2011;20:1438-1455.

57. Milakovic T, Johnson GV. Mitochondrial respiration and ATP production are significantly impaired in striatal cells expressing mutant huntingtin. J Biol Chem. 2005;280:30773-30782.

58. Seong IS, Ivanova E, Lee JM, et al. HD CAG repeat implicates a dominant property of huntingtin in mitochondrial energy metabolism. Hum Mol Genet. 2005;14: 2871-2880.

59. Choo YS, Johnson GV, MacDonald M, et al. Mutant huntingtin directly increases susceptibility of mitochondria to the calcium-induced permeability transition and cytochrome c release. Hum Mol Genet. 2004;13: 1407-1420.

60. Guo X, Disatnik MH, Monbureau M, Shamloo M, Mochly-Rosen D, Qi X. Inhibition of mitochondrial fragmentation diminishes Huntington's disease-associated neurodegeneration. J Clin Invest. 2013;123:5371-5388.

61. Lee CF, Chern Y. Adenosine receptors and Huntington's disease. Int Rev Neurobiol. 2014;119:195-232.

62. Ju TC, Chen HM, Lin JT, et al. Nuclear translocation of AMPK-alpha1 potentiates striatal neurodegeneration in Huntington's disease. J Cell Biol. 2011;194: 209-227.

63. Lin JT, Chang WC, Chen HM, et al. Regulation of feedback between protein kinase $\mathrm{A}$ and the proteasome system worsens Huntington's disease. Mol Cell Biol. 2013;33:1073-1084.

64. Chao MV. Neurotrophins and their receptors: A convergence point for many signalling pathways. Nat Rev Neurosci. 2003;4:299-309.

65. Zuccato C, Cattaneo E. Role of brain-derived neurotrophic factor in Huntington's disease. Prog Neurobiol. 2007;81:294-330. 
66. Zuccato C, Ciammola A, Rigamonti D, et al. Loss of huntingtin-mediated BDNF gene transcription in Huntington's disease. Science. 2001;293:493-498.

67. Zuccato C, Tartari M, Crotti A, et al. Huntingtin interacts with REST/NRSF to modulate the transcription of NRSE-controlled neuronal genes. Nat Genet. 2003;35: 76-83.

68. Dompierre JP, Godin JD, Charrin BC, et al. Histone deacetylase 6 inhibition compensates for the transport deficit in Huntington's disease by increasing tubulin acetylation. J Neurosci. 2007;27:3571-3583.

69. del Toro D, Canals JM, Gines S, Kojima M, Egea G, Alberch J. Mutant huntingtin impairs the post-Golgi trafficking of brain-derived neurotrophic factor but not its Val66Met polymorphism. J Neurosci. 2006;26: $12748-12757$

70. Wu LL, Fan Y, Li S, Li XJ, Zhou XF. Huntingtinassociated protein-1 interacts with pro-brain-derived neurotrophic factor and mediates its transport and release. J Biol Chem. 2010;285:5614-5623.

71. Borrell-Pagès M, Canals JM, Cordelières FP, et al. Cystamine and cysteamine increase brain levels of BDNF in Huntington disease via HSJ1b and transglutaminase. J Clin Invest. 2006;116:1410-1424.

72. Lynch G, Kramar EA, Rex CS, et al. Brain-derived neurotrophic factor restores synaptic plasticity in a knockin mouse model of Huntington's disease. J Neurosci. 2007;27:4424-4434.

73. Gharami K, Xie Y, An JJ, Tonegawa S, Xu B. Brainderived neurotrophic factor over-expression in the forebrain ameliorates Huntington's disease phenotypes in mice. J Neurochem. 2008;105:369-379.

74. Peng Q, Masuda N, Jiang M, et al. The antidepressant sertraline improves the phenotype, promotes neurogenesis and increases BDNF levels in the R6/2 Huntington's disease mouse model. Exp Neurol. 2008;210: 154-163.

75. Simmons DA, Rex CS, Palmer L, et al. Up-regulating BDNF with an ampakine rescues synaptic plasticity and memory in Huntington's disease knockin mice. Proc Natl Acad Sci USA. 2009;106:4906-4911.

76. Giralt A, Friedman HC, Caneda-Ferron B, et al. BDNF regulation under GFAP promoter provides engineered astrocytes as a new approach for long-term protection in Huntington's disease. Gene Ther. 2010;17:1294-1308.

77. Xie Y, Hayden MR, Xu B. BDNF overexpression in the forebrain rescues Huntington's disease phenotypes in YAC128 mice. J Neurosci. 2010;30:14708-14718.

78. Goldberg AL. Protein degradation and protection against misfolded or damaged proteins. Nature. 2003; 426:895-899.

79. Gusella JF, MacDonald ME. Huntington's disease: Seeing the pathogenic process through a genetic lens. Trends Biochem Sci. 2006;31:533-540.

80. Kopito RR. Aggresomes, inclusion bodies and protein aggregation. Trends Cell Biol. 2000;10:524-530.

81. Demartino GN, Gillette TG. Proteasomes: Machines for all reasons. Cell. 2007;129:659-662.

82. Hershko A, Ciechanover A. The ubiquitin system. Annu Rev Biochem. 1998;67:425-479.

83. Bennett EJ, Shaler TA, Woodman B, et al. Global changes to the ubiquitin system in Huntington's disease. Nature. 2007;448:704-708.
84. Finkbeiner S, Mitra S. The ubiquitin-proteasome pathway in Huntington's disease. ScientificWorldJournal. 2008;8:421-433.

85. Ortega Z, Lucas JJ. Ubiquitin-proteasome system involvement in Huntington's disease. Front Mol Neurosci. 2014;7:77.

86. Seo H, Sonntag KC, Isacson O. Generalized brain and skin proteasome inhibition in Huntington's disease. Ann Neurol. 2004;56:319-328.

87. Wang J, Wang CE, Orr A, Tydlacka S, Li SH, Li XJ. Impaired ubiquitin-proteasome system activity in the synapses of Huntington's disease mice. J Cell Biol. 2008;180:1177-1189.

88. Zheng Q, Huang T, Zhang L, et al. Dysregulation of ubiquitin-proteasome system in neurodegenerative diseases. Front Aging Neurosci. 2016;8:303.

89. Seo H, Sonntag KC, Kim W, Cattaneo E, Isacson O. Proteasome activator enhances survival of Huntington's disease neuronal model cells. PLoS One. 2007;2:e238.

90. Wong HK, Bauer PO, Kurosawa M, et al. Blocking acidsensing ion channel 1 alleviates Huntington's disease pathology via an ubiquitin-proteasomesystem-dependent mechanism. Hum Mol Genet. 2008;17:3223-3235.

91. Jia H, Kast RJ, Steffan JS, Thomas EA. Selective histone deacetylase (HDAC) inhibition imparts beneficial effects in Huntington's disease mice: Implications for the ubiquitin-proteasomal and autophagy systems. Hum Mol Genet. 2012;21:5280-5293.

92. Kim W, Seo H. Baclofen, a GABAB receptor agonist, enhances ubiquitin-proteasome system functioning and neuronal survival in Huntington's disease model mice. Biochem Biophys Res Commun. 2014;443:706-711.

93. Liu Y, Hettinger CL, Zhang D, Rezvani K, Wang X, Wang H. Sulforaphane enhances proteasomal and autophagic activities in mice and is a potential therapeutic reagent for Huntington's disease. J Neurochem. 2014; 129:539-547.

94. Jeon J, Kim W, Jang J, Isacson O, Seo H. Gene therapy by proteasome activator, PA28gamma, improves motor coordination and proteasome function in Huntington's disease YAC128 mice. Neuroscience. 2016;324:20-28.

95. Nixon RA. The role of autophagy in neurodegenerative disease. Nat Med. 2013;19:983-997.

96. Gelman A, Rawet-Slobodkin M, Elazar Z. Huntingtin facilitates selective autophagy. Nat Cell Biol. 2015; 17:214-215.

97. Rui YN, Xu Z, Patel B, et al. Huntingtin functions as a scaffold for selective macroautophagy. Nat Cell Biol. 2015;17:262-275.

98. Kiriyama Y, Nochi H. The function of autophagy in neurodegenerative diseases. Int J Mol Sci. 2015;16: 26797-26812.

99. Martinez-Vicente M, Talloczy Z, Wong E, et al. Cargo recognition failure is responsible for inefficient autophagy in Huntington's disease. Nat Neurosci. 2010;13: 567-576.

100. Sarkar S, Perlstein EO, Imarisio S, et al. Small molecules enhance autophagy and reduce toxicity in Huntington's disease models. Nat Chem Biol. 2007;3: 331-338.

101. Williams A, Sarkar S, Cuddon P, et al. Nove targets for Huntington's disease in an mTOR-independent autophagy pathway. Nat Chem Biol. 2008;4:295-305. 
102. Koga H, Martinez-Vicente M, Arias E, Kaushik S, Sulzer D, Cuervo AM. Constitutive upregulation of chaperone-mediated autophagy in Huntington's disease. J Neurosci. 2011;31:18492-18505.

103. Martin DD, Ladha S, Ehrnhoefer DE, Hayden MR. Autophagy in Huntington disease and huntingtin in autophagy. Trends Neurosci. 2015;38:26-35.

104. Yu ZX, Li SH, Evans J, Pillarisetti A, Li H, Li XJ. Mutant huntingtin causes context-dependent neurodegeneration in mice with Huntington's disease. J Neurosci. 2003;23:2193-2202.

105. Hsiao HY, Chern Y. Targeting glial cells to elucidate the pathogenesis of Huntington's disease. Mol Neurobiol. 2010;41(2-3):248-255.

106. Lee W, Reyes RC, Gottipati MK, et al. Enhanced $\mathrm{Ca}(2+)$-dependent glutamate release from astrocytes of the BACHD Huntington's disease mouse model. Neurobiol Dis. 2013;58:192-199.

107. Chou SY, Weng JY, Lai HL, et al. Expandedpolyglutamine huntingtin protein suppresses the secretion and production of a chemokine (CCL5/RANTES) by astrocytes. J Neurosci. 2008;28:3277-3290.

108. Bradford J, Shin JY, Roberts M, et al. Mutant huntingtin in glial cells exacerbates neurological symptoms of Huntington disease mice. J Biol Chem. 2010;285: 10653-10661.

109. Hsiao HY, Chen YC, Chen HM, Tu PH, Chern Y. A critical role of astrocyte-mediated nuclear factorkappaB-dependent inflammation in Huntington's disease. Hum Mol Genet. 2013;22:1826-1842.

110. Crotti A, Benner C, Kerman BE, et al. Mutant Huntingtin promotes autonomous microglia activation via myeloid lineage-determining factors. Nat Neurosci. 2014; 17:513-521.

111. Huang B, Wei W, Wang G, et al. Mutant huntingtin downregulates myelin regulatory factor-mediated myelin gene expression and affects mature oligodendrocytes. Neuron. 2015;85:1212-1226.

112. Powers WJ, Videen TO, Markham J, et al. Selective defect of in vivo glycolysis in early Huntington's disease striatum. Proc Natl Acad Sci USA. 2007;104:29452949.

113. Lee CY, Cantle JP, Yang XW. Genetic manipulations of mutant huntingtin in mice: New insights into Huntington's disease pathogenesis. FEBS J. 2013;280: 4382-4394.

114. Wojtowicz AM, Dvorzhak A, Semtner M, Grantyn R. Reduced tonic inhibition in striatal output neurons from Huntington mice due to loss of astrocytic GABA release through GAT-3. Front Neural Circuits. 2013;7:188.

115. Wang L, Lin F, Wang J, et al. Expression of mutant $\mathrm{N}$ terminal huntingtin fragment (htt552-100Q) in astrocytes suppresses the secretion of BDNF. Brain Res. 2012;1449:69-82.

116. Tong X, Ao Y, Faas GC, et al. Astrocyte Kir4.1 ion channel deficits contribute to neuronal dysfunction in Huntington's disease model mice. Nat Neurosci. 2014;17:694-703.

117. Jiang R, Diaz-Castro B, Looger LL, Khakh BS. Dysfunctional calcium and glutamate signaling in striatal astrocytes from Huntington's disease Model Mice. J Neurosci. 2016;36:3453-3470.
118. Benraiss A, Wang S, Herrlinger S, et al. Human glia can both induce and rescue aspects of disease phenotype in Huntington disease. Nat Commun. 2016;7: 11758.

119. Chiu E, Mackay IR, Bhathal PB. Hepatic morphology in Huntington's chorea. J Neurol Neurosurg Psychiatry. 1975;38:1000-1002.

120. Chiang MC, Chen HM, Lai HL, et al. The A2A adenosine receptor rescues the urea cycle deficiency of Huntington's disease by enhancing the activity of the ubiquitin-proteasome system. Hum Mol Genet. 2009; 18:2929-2942.

121. Björkqvist M, Wild EJ, Thiele J, et al. A novel pathogenic pathway of immune activation detectable before clinical onset in Huntington's disease. J Exp Med. 2008;205:1869-1877.

122. Weiss A, Träger U, Wild EJ, et al. Mutant huntingtin fragmentation in immune cells tracks Huntington's disease progression. J Clin Invest. 2012;122:37313736.

123. Ferré S, Agnati LF, Ciruela F, et al. Neurotransmitter receptor heteromers and their integrative role in "local modules": The striatal spine module. Brain Res Rev. 2007;55:55-67.

124. Gerfen CR. Basal ganglia. In: The Rat Nervous System. Paxinos G (Ed.), Amsterdam: Elsevier Academic Press; 2004: pp. 445508.

125. Araque A, Parpura V, Sanzgiri RP, Haydon PG. Tripartite synapses: Glia, the unacknowledged partner. Trends Neurosci. 1999;22:208-215.

126. Rice ME, Patel JC, Cragg SJ. Dopamine release in the basal ganglia. Neuroscience. 2011;198:112-137.

127. Pascual O, Casper KB, Kubera C, et al. Astrocytic purinergic signaling coordinates synaptic networks. Science. 2005;310:113-116.

128. Cunha RA. How does adenosine control neuronal dysfunction and neurodegeneration? J Neurochem. 2016; 139:1019-1055.

129. Ciruela F, Casadó V, Rodrigues RJ, et al. Presynaptic control of striatal glutamatergic neurotransmission by adenosine A1-A2A receptor heteromers. J Neurosci. 2006;26:2080-2087.

130. Popoli P, Betto P, Reggio R, Ricciarello G. Adenosine A2A receptor stimulation enhances striatal extracellular glutamate levels in rats. Eur J Pharmacol. 1995; 287:215-217.

131. Solinas M, Ferré S, You ZB, Karcz-Kubicha M, Popoli $\mathrm{P}$, Goldberg SR. Caffeine induces dopamine and glutamate release in the shell of the nucleus accumbens. $\mathrm{J}$ Neurosci. 2002;22:6321-6324.

132. Borycz J, Pereira MF, Melani A, et al. Differential glutamate-dependent and glutamate-independent adenosine A1 receptor-mediated modulation of dopamine release in different striatal compartments. J Neurochem. 2007; 101:355-363.

133. Quiroz C, Luján R, Uchigashima M, et al. Key modulatory role of presynaptic adenosine $\mathrm{A} 2 \mathrm{~A}$ receptors in cortical neurotransmission to the striatal direct pathway. ScientificWorldJournal. 2009;9:1321-1344.

134. Quiroz C, Orrú M, Rea W, et al. Local Control of Extracellular Dopamine Levels in the Medial Nucleus Accumbens by a Glutamatergic Projection from the Infralimbic Cortex. J Neurosci. 2016;36:851-859. 
135. Cristóvão-Ferreira S, Navarro G, Brugarolas $\mathrm{M}$, et al. A1R-A2AR heteromers coupled to Gs and G i/0 proteins modulate GABA transport into astrocytes. Purinergic Signal. 2013;9:433-449.

136. Ferré S, Fredholm BB, Morelli M, Popoli P, Fuxe K. Adenosine-dopamin receptor-receptor interactions as an integrative mechanism in the basal ganglia. Trends Neurosci. 1997;20:482-487.

137. Ferre S, O'Connor WT, Svenningsson P, et al. Dopamine D1 receptor-mediated facilitation of GABAergic neurotransmission in the rat strioentopenduncular pathway and its modulation by adenosine A1 receptormediated mechanisms. Eur J Neurosci. 1996;8:15451553.

138. Sokoloff P, Le Foll B. The dopamine D3 receptor, a quarter century later. Eur J Neurosci. 2017;45:2-19.

139. Ginés S, Hillion J, Torvinen M, et al. Dopamine D1 and adenosine A1 receptors form functionally interacting heteromeric complexes. Proc Natl Acad Sci USA. 2000;97:8606-8611.

140. Hillion J, Canals M, Torvinen M, et al. Coaggregation, cointernalization, and codesensitization of adenosine A2A receptors and dopamine D2 receptors. J Biol Chem. 2002;277:18091-18097.

141. Navarro G, Cordomí A, Casadó-Anguera V, et al. Evidence for functional pre-coupled complexes of receptor heteromers and adenylyl cyclase. Nat Commun. 2018; 9:1242.

142. Ferré S, Bonaventura J, Zhu W, et al. Essential control of the function of the striatopallidal neuron by precoupled complexes of adenosine A2A-dopamine D2 receptor heterotetramers and adenylyl cyclase. Front Pharmacol. 2018;9:243

143. Alsene K, Deckert J, Sand P, de Wit H. Association between A2a receptor gene polymorphisms and caffeineinduced anxiety. Neuropsychopharmacology. 2003;28: 1694-1702.

144. Childs E, Hohoff C, Deckert J, Xu K, Badner J, de Wit H. Association between ADORA2A and DRD2 polymorphisms and caffeine-induced anxiety. Neuropsychopharmacology. 2008;33:2791-2800.

145. Rogers PJ, Hohoff C, Heatherley SV, et al. Association of the anxiogenic and alerting effects of caffeine with ADORA2A and ADORA1 polymorphisms and habitual level of caffeine consumption. Neuropsychopharmacology. 2010;35:1973-1983.

146. Shinohara M, Saitoh M, Nishizawa D, et al. ADORA2A polymorphism predisposes children to encephalopathy with febrile status epilepticus. Neurology. 2013;80: 1571-1576.

147. Dhaenens CM, Burnouf S, Simonin C, et al. A genetic variation in the ADORA2A gene modifies age at onset in Huntington's disease. Neurobiol Dis. 2009;35:474476.

148. Taherzadeh-Fard E, Saft C, Wieczorek S, Epplen JT, Arning L. Age at onset in Huntington's disease: Replication study on the associations of ADORA2A, HAP1 and OGG1. Neurogenetics. 2010;11:435-439.

149. Simonin C, Duru C, Salleron J, et al. Association between caffeine intake and age at onset in Huntington's disease. Neurobiol Dis. 2013;58:179-182.

150. Karcz-Kubicha M, Antoniou K, Terasmaa A, et al. Involvement of adenosine $\mathrm{A} 1$ and $\mathrm{A} 2 \mathrm{~A}$ receptors in the motor effects of caffeine after its acute and chronic administration. Neuropsychopharmacology. 2003;28: 1281-1291.

151. Blum D, Gall D, Galas MC, d'Alcantara P, Bantubungi $\mathrm{K}$, Schiffmann SN. The adenosine A1 receptor agonist adenosine amine congener exerts a neuroprotective effect against the development of striatal lesions and motor impairments in the 3-nitropropionic acid model of neurotoxicity. J Neurosci. 2002;22:9122-9133.

152. Mievis S, Blum D, Ledent C. A2A receptor knockout worsens survival and motor behaviour in a transgenic mouse model of Huntington's disease. Neurobiol Dis. 2011;41:570-576.

153. Chou SY, Lee YC, Chen HM, et al. CGS21680 attenuates symptoms of Huntington's disease in a transgenic mouse model. J Neurochem. 2005;93:310-320.

154. Cornelis MC, El-Sohemy A, Campos H. Genetic polymorphism of the adenosine $\mathrm{A} 2 \mathrm{~A}$ receptor is associated with habitual caffeine consumption. Am J Clin Nutr 2007;86:240-244.

155. Coffee and Caffeine Genetics Consortium, Cornelis MC, Byrne EM, et al. Genome-wide meta-analysis identifies six novel loci associated with habitual coffee consumption. Mol Psychiatry. 2015;20:647-656.

156. Paul S, Elsinga PH, Ishiwata K, Dierckx RA, van Waarde A. Adenosine A(1) receptors in the central nervous system: Their functions in health and disease, and possible elucidation by PET imaging. Curr Med Chem. 2011;18:4820-4835.

157. von Lubitz DK, Dambrosia JM, Kempski O, Redmond DJ. Cyclohexyl adenosine protects against neuronal death following ischemia in the CA1 region of gerbil hippocampus. Stroke. 1988;19:1133-1139.

158. Zuchora B, Turski WA, Wielosz M, Urbańska EM. Protective effect of adenosine receptor agonists in a new model of epilepsy-seizures evoked by mitochondrial toxin, 3-nitropropionic acid, in mice. Neurosci Lett. 2001;305:91-94.

159. Alfinito PD, Wang SP, Manzino L, Rijhsinghani S, Zeevalk GD, Sonsalla PK. Adenosinergic protection of dopaminergic and GABAergic neurons against mitochondrial inhibition through receptors located in the substantia nigra and striatum, respectively. J Neurosci. 2003;23:10982-10987.

160. Bauer A, Zilles K, Matusch A, Holzmann C, Riess O, von Hörsten S. Regional and subtype selective changes of neurotransmitter receptor density in a rat transgenic for the Huntington's disease mutation. J Neurochem. 2005;94:639-650.

161. Ferrante A, Martire A, Pepponi R, et al. Expression, pharmacology and functional activity of adenosine A1 receptors in genetic models of Huntington's disease. Neurobiol Dis. 2014;71:193-204.

162. Matusch A, Saft C, Elmenhorst D, et al. Cross sectional PET study of cerebral adenosine $\mathrm{A}^{1}$ receptors in premanifest and manifest Huntington's disease. Eur J Nucl Med Mol Imaging. 2014;41:1210-1220.

163. Martinez-Mir MI, Probst A, Palacios JM. Adenosine A2 receptors: Selective localization in the human basal ganglia and alterations with disease. Neuroscience 1991; 42:697-706.

164. Cha JH, Frey AS, Alsdorf SA, et al. Altered neurotransmitter receptor expression in transgenic mouse models 
of Huntington's disease. Philos Trans R Soc Lond B Biol Sci. 1999;354:981-989.

165. Ishiwata K, Ogi N, Hayakawa N, et al. Adenosine A2A receptor imaging with $[11 \mathrm{C}] \mathrm{KF} 18446 \mathrm{PET}$ in the rat brain after quinolinic acid lesion: Comparison with the dopamine receptor imaging. Ann Nucl Med. 2002; 16:467-475.

166. Orrú M, Zanoveli JM, Quiroz C, Nguyen HP, Guitart X, Ferré S. Functional changes in postsynaptic adenosine $\mathrm{A}(2 \mathrm{~A})$ receptors during early stages of a rat model of Huntington disease. Exp Neurol. 2011;232:76-80.

167. Chan EY, Luthi-Carter R, Strand A, et al. Increased huntingtin protein length reduces the number of polyglutamine-induced gene expression changes in mouse models of Huntington's disease. Hum Mol Genet. 2002;11:1939-1951.

168. Chiang MC, Lee YC, Huang CL, Chern Y. cAMPresponse element-binding protein contributes to suppression of the $\mathrm{A} 2 \mathrm{~A}$ adenosine receptor promoter by mutant Huntingtin with expanded polyglutamine residues. J Biol Chem. 2005;280:14331-14340.

169. Tarditi A, Camurri A, Varani K, et al. Early and transient alteration of adenosine $\mathrm{A} 2 \mathrm{~A}$ receptor signaling in a mouse model of Huntington disease. Neurobiol Dis. 2006;23:44-53.

170. Villar-Menéndez I, Blanch M, Tyebji S, et al. Increased 5methylcytosine and decreased 5-hydroxymethylcytosine levels are associated with reduced striatal A2AR levels in Huntington's disease. Neuromolecular Med. 2013; 15:295-309.

171. Guitart X, Bonaventura J, Rea W, et al. Equilibrative nucleoside transporter ENT1 as a biomarker of Huntington disease. Neurobiol Dis. 2016;96:47-53.

172. Steffan JS, Kazantsev A, Spasic-Boskovic O, et al. The Huntington's disease protein interacts with p53 and CREB-binding protein and represses transcription. Proc Natl Acad Sci USA. 2000;97:6763-6768.

173. Nucifora FC Jr., Sasaki M, Peters MF, et al. Interference by huntingtin and atrophin-1 with cbp-mediated transcription leading to cellular toxicity. Science. 2001;291:2423-2428.

174. Dunah AW, Jeong H, Griffin A, et al. Sp1 and TAFII130 transcriptional activity disrupted in early Huntington's disease. Science. 2002;296:2238-2243.

175. Li SH, Cheng AL, Zhou H, et al. Interaction of Huntington disease protein with transcriptional activator Sp1. Mol Cell Biol. 2002;22:1277-1287.

176. Cha JH, Kosinski CM, Kerner JA, et al. Altered brain neurotransmitter receptors in transgenic mice expressing a portion of an abnormal human huntington disease gene. Proc Natl Acad Sci USA. 1998;95:6480-6485.

177. Buira SP, Dentesano G, Albasanz JL, et al. DNA methylation and Yin Yang-1 repress adenosine A2A receptor levels in human brain. J Neurochem. 2010;115: 283-295.

178. Mangiarini L, Sathasivam K, Seller M, et al. Exon 1 of the HD gene with an expanded CAG repeat is sufficient to cause a progressive neurological phenotype in transgenic mice. Cell. 1996;87:493-506.

179. Vonsattel JP. Huntington disease models and human neuropathology: Similarities and differences. Acta Neuropathol. 2008;115:55-69.
180. Varani K, Rigamonti D, Sipione S, et al. Aberrant amplification of $\mathrm{A}(2 \mathrm{~A})$ receptor signaling in striatal cells expressing mutant huntingtin. FASEB J. 2001;15: 1245-1247.

181. Varani K, Bachoud-Lévi AC, Mariotti C, et al. Biological abnormalities of peripheral $\mathrm{A}(2 \mathrm{~A})$ receptors in a large representation of polyglutamine disorders and Huntington's disease stages. Neurobiol Dis. 2007;27: 36-43.

182. Maglione V, Cannella M, Martino T, De Blasi A, Frati L, Squitieri F. The platelet maximum number of A2Areceptor binding sites (Bmax) linearly correlates with age at onset and CAG repeat expansion in Huntington's disease patients with predominant chorea. Neurosci Lett. 2006;393:27-30.

183. Roussakis AA, Piccini P. PET Imaging in Huntington's Disease. J Huntingtons Dis. 2015;4:287-296.

184. Bauer A, Holschbach MH, Meyer PT, et al. In vivo imaging of adenosine A1 receptors in the human brain with $[18 \mathrm{~F}] \mathrm{CPFPX}$ and positron emission tomography. Neuroimage. 2003;19:1760-1769.

185. Holschbach MH, Olsson RA, Bier D, et al. Synthesis and evaluation of no-carrier-added 8-cyclopentyl-3-(3[(18)F]fluoropropyl)-1-propylxanthine ([(18)F]CPFPX): A potent and selective $\mathrm{A}(1)$-adenosine receptor antagonist for in vivo imaging. J Med Chem. 2002;45: 5150-5156.

186. Meyer PT, Elmenhorst D, Boy C, et al. Effect of aging on cerebral A1 adenosine receptors: A [18F]CPFPX PET study in humans. Neurobiol Aging. 2007;28: 1914-1924.

187. Khanapur S, Waarde Av, Ishiwata K, Leenders KL, Dierckx RA, Elsinga PH. Adenosine A(2A) receptor antagonists as positron emission tomography (PET) tracers. Curr Med Chem. 2014;21:312-328.

188. van Waarde A, Dierckx RAJO, Zhou X, et al. Potential therapeutic applications of adenosine $\mathrm{A}(2 \mathrm{~A})$ receptor ligands and opportunities for $\mathrm{A}(2 \mathrm{~A})$ receptor imaging. Med Res Rev. 2018;38:5-56.

189. Moresco RM, Todde S, Belloli S, et al. In vivo imaging of adenosine $\mathrm{A} 2 \mathrm{~A}$ receptors in rat and primate brain using [11C]SCH442416. Eur J Nucl Med Mol Imaging. 2005;32:405-413.

190. Zhou X, Boellaard R, Ishiwata K, et al. In Vivo Evaluation of (11)C-preladenant for PET imaging of adenosine $\mathrm{A}(2 \mathrm{~A})$ receptors in the conscious monkey. $\mathrm{J}$ Nucl Med. 2017;58:762-767.

191. Zhou X, Khanapur S, de Jong JR, et al. In vivo evaluation of [(11)C]preladenant positron emission tomography for quantification of adenosine $\mathrm{A}(2 \mathrm{~A})$ receptors in the rat brain. J Cereb Blood Flow Metab. 2017;37:577589.

192. Sakata M, Ishibashi K, Imai M, et al. Initial evaluation of an adenosine $\mathrm{A}(2 \mathrm{~A})$ receptor ligand, (11)C-preladenant, in healthy human subjects. J Nucl Med. 2017;58: 1464-1470.

193. von Hörsten S, Schmitt I, Nguyen HP, et al. Transgenic rat model of Huntington's disease. Hum Mol Genet. 2003;12:617-624.

194. Orrú M, Bakešová J, Brugarolas M, et al. Striatal preand postsynaptic profile of adenosine $\mathrm{A}(2 \mathrm{~A})$ receptor antagonists. PLoS One. 2011;6:e16088. 
195. Menalled LB, Kudwa AE, Miller S, et al. Comprehensive behavioral and molecular characterization of a new knock-in mouse model of Huntington's disease: zQ175. PLoS One. 2012;7:e49838.

196. Boison D, Chen JF, Fredholm BB. Adenosine signaling and function in glial cells. Cell Death Differ. 2010;17: 1071-1082.

197. Parkinson FE, Damaraju VL, Graham K, et al. Molecular biology of nucleoside transporters and their distributions and functions in the brain. Curr Top Med Chem. 2011;11:948-972.

198. Dulla CG, Masino SA. Physiology and metabolic regulation of adenosine: Mechanisms. In: Adenosine. A Key Link Between Metabolism and Brain Activity. Masino S, Boison D (Eds.) New York: Springer; 2013: pp. 87-107.

199. Alanko L, Porkka-Heiskanen T, Soinila S. Localization of equilibrative nucleoside transporters in the rat brain. J Chem Neuroanat. 2006;31:162-168.

200. Bicket A, Mehrabi P, Naydenova Z, et al. Novel regulation of equlibrative nucleoside transporter 1 (ENT1) by receptor-stimulated $\mathrm{Ca} 2+$-dependent calmodulin binding. Am J Physiol Cell Physiol. 2016;310:C808C820.

201. Kao YH, Lin MS, Chen CM, et al. Targeting ENT1 and adenosine tone for the treatment of Huntington's disease. Hum Mol Genet. 2017;26:467-478.

202. Alston TA, Mela L, Bright HJ. 3-Nitropropionate, the toxic substance of Indigofera, is a suicide inactivator of succinate dehydrogenase. Proc Natl Acad Sci USA. 1977:74;3767-3771.

203. Brouillet E, Jenkins BG, Hyman BT, et al. Agedependent vulnerability of the striatum to the mitochondrial toxin 3-nitropropionic acid. J Neurochem. 1993; 60:356-359.

204. Jacobson KA, Balasubramanian R, Deflorian F, Gao ZG. G protein-coupled adenosine (P1) and P2Y receptors: Ligand design and receptor interactions. Purinergic Signal. 2012;8:419-436.

205. Shear DA, Dong J, Gundy CD, Haik-Creguer KL, Dunbar GL. Comparison of intrastriatal injections of quinolinic acid and 3-nitropropionic acid for use in animal models of Huntington's disease. Prog Neuropsychopharmacol Biol Psychiatry. 1998;22:1217-1240.

206. Andreassen OA, Ferrante RJ, Hughes DB, et al. Malonate and 3-nitropropionic acid neurotoxicity are reduced in transgenic mice expressing a caspase-1 dominant-negative mutant. J Neurochem. 2000;75: 847-852.

207. Beal MF, Brouillet E, Jenkins B, Henshaw R, Rosen B, Hyman BT. Age-dependent striatal excitotoxic lesions produced by the endogenous mitochondrial inhibitor malonate. J Neurochem. 1993;61:1147-1150.

208. Messam CA, Greene JG, Greenamyre JT, Robinson MB. Intrastriatal injections of the succinate dehydrogenase inhibitor, malonate, cause a rise in extracellular amino acids that is blocked by MK-801. Brain Res. 1995;684:221-224.

209. Fink JS, Kalda A, Ryu H, et al. Genetic and pharmacological inactivation of the adenosine A2A receptor attenuates 3-nitropropionic acid-induced striatal damage. J Neurochem. 2004;88:538-544.
210. Galluzzo M, Pintor A, Pezzola A, Grieco R, Borsini F, Popoli P. Behavioural and neurochemical characterization of the adenosine A2A receptor antagonist ST1535. Eur J Pharmacol. 2008;579:149-152.

211. Reggio R, Pezzola A, Popoli P. The intrastratial injection of an adenosine $\mathrm{A}(2)$ receptor antagonist prevents frontal cortex EEG abnormalities in a rat model of Huntington's disease. Brain Res. 1999;831:315-318.

212. Scattoni ML, Valanzano A, Pezzola A, et al. Adenosine A2A receptor blockade before striatal excitotoxic lesions prevents long term behavioural disturbances in the quinolinic rat model of Huntington's disease. Behav Brain Res. 2007;176:216-221.

213. Tebano MT, Pintor A, Frank C, et al. Adenosine A2A receptor blockade differentially influences excitotoxic mechanisms at pre- and postsynaptic sites in the rat striatum. J Neurosci Res. 2004;77:100-107.

214. Huang QY, Wei C, Yu L, et al. Adenosine A2A receptors in bone marrow-derived cells but not in forebrain neurons are important contributors to 3-nitropropionic acid-induced striatal damage as revealed by cell-typeselective inactivation. J Neurosci. 2006;26:1137111378.

215. Blum D, Hourez R, Galas MC, Popoli P, Schiffmann SN. Adenosine receptors and Huntington's disease: Implications for pathogenesis and therapeutics. Lancet Neurol. 2003;2:366-374.

216. Pouladi MA, Morton A, Hayden MR. Choosing an animal model for the study of Huntington's disease. Nat Rev Neurosci. 2013;14:708-721.

217. Ferrante RJ. Mouse models of Huntington's disease and methodological considerations for therapeutic trials. Biochim Biophys Acta. 2009;1792:506-520.

218. Li JY, Popovic N, Brundin P. The use of the R6 transgenic mouse models of Huntington's disease in attempts to develop novel therapeutic strategies. NeuroRx. 2005;2:447-464.

219. Menalled LB. Knock-in mouse models of Huntington's disease. NeuroRx. 2005;2:465-470.

220. Menalled LB, Chesselet MF. Mouse models of Huntington's disease. Trends Pharmacol Sci. 2002;23:32-39.

221. Luthi-Carter R, Strand A, Peters NL, et al. Decreased expression of striatal signaling genes in a mouse model of Huntington's disease. Hum Mol Genet. 2000;9:1259-1271.

222. Cepeda C, Cummings DM, Hickey MA, et al. Rescuing the corticostriatal synaptic disconnection in the R6/2 mouse model of Huntington's disease: Exercise, adenosine receptors and ampakines. PLoS Curr. 2010;2: pii:RRN1182.

223. Huang NK, Lin JH, Lin JT, et al. A new drug design targeting the adenosinergic system for Huntington's disease. PLoS One. 2011;6:e20934.

224. Potenza RL, Tebano MT, Martire A, et al. Adenosine $\mathrm{A}(2 \mathrm{~A})$ receptors modulate $\mathrm{BDNF}$ both in normal conditions and in experimental models of Huntington's disease. Purinergic Signal. 2007;3:333-338.

225. Martire A, Pepponi R, Domenici MR, Ferrante A, Chiodi V, Popoli P. BDNF prevents NMDA-induced toxicity in models of Huntington's disease: The effects are genotype specific and adenosine A2A receptor is involved. J Neurochem. 2013;125:225-235. 
226. Domenici MR, Scattoni ML, Martire A, et al. Behavioral and electrophysiological effects of the adenosine A2A receptor antagonist SCH 58261 in R6/2 Huntington's disease mice. Neurobiol Dis. 2007;28:197-205.

227. Gianfriddo M, Melani A, Turchi D, Giovannini MG, Pedata F. Adenosine and glutamate extracellular concentrations and mitogen-activated protein kinases in the striatum of Huntington transgenic mice. Selective antagonism of adenosine A2A receptors reduces transmitter outflow. Neurobiol Dis. 2004;17:77-88.

228. Cipriani S, Bizzoco E, Gianfriddo M, Melani A, Vannucchi MG, Pedata F. Adenosine A2A receptor antagonism increases nNOS-immunoreactive neurons in the striatum of Huntington transgenic mice. Exp Neurol. 2008;13:163-170.

229. Li W, Silva HB, Real J, et al. Inactivation of adenosine A2A receptors reverses working memory deficits at early stages of Huntington's disease models. Neurobiol Dis. 2015;79:70-80.

230. Tyebji S, Saavedra A, Canas PM, et al. Hyperactivation of D1 and A2A receptors contributes to cognitive dysfunction in Huntington's disease. Neurobiol Dis. 2015; 74:41-57.

231. Chen JB, Liu EM, Chern TR, et al. Design and synthesis of novel dual-action compounds targeting the adenosine $\mathrm{A}(2 \mathrm{~A})$ receptor and adenosine transporter for neuroprotection. ChemMedChem. 2011;6:1390-1400.

232. Lin CH, Tallaksen-Greene S, Chien WM, et al. Neurological abnormalities in a knock-in mouse model of
Huntington's disease. Hum Mol Genet. 2001;10:137144.

233. Guitart X, Chern Y, Ferré S. Targeting the equilibrative nucleoside transporter ENT1 in Huntington disease. Oncotarget. 2017;8:12550-12551.

234. Ferré S, Herrera-Marschitz M, Grabowska-Andén M, Ungerstedt U, Casas M, Andén NE. Postsynaptic dopamine/adenosine interaction: I. Adenosine analogues inhibit dopamine D2-mediated behaviour in short-term reserpinized mice. Eur J Pharmacol. 1991;192:25-30.

235. Ferré S, Popoli P, Giménez-Llort L, et al. Postsynaptic antagonistic interaction between adenosine A1 and dopamine D1 receptors. Neuroreport. 1994;6:73-76.

236. Ferré S, Quiroz C, Guitart X, et al. Pivotal role of adenosine neurotransmission in restless legs syndrome. Front Neurosci. 2018;11:722.

Address correspondence to

David Blum, PhD

University of Lille Inserm

Inserm UMR-S 1172

Place Verdun

Lille Cedex

CHU Lille 59045

France

E-mail: david.blum@inserm.fr 